\title{
The Reform of October 1979: How It Happened and Why
}

\author{
David E. Lindsey, Athanasios Orphanides, and Robert H. Rasche
}

\begin{abstract}
This study offers a historical review of the monetary policy reform of October 6, 1979, and discusses the influences behind it and its significance. We lay out the record from the start of 1979 through the spring of 1980, relying almost exclusively on contemporaneous sources, including the recently released transcripts of Federal Open Market Committee (FOMC) meetings during 1979. We then present and discuss in detail the reasons for the FOMC's adoption of the reform and the communications challenge presented to the Committee during this period. Further, we examine whether the essential characteristics of the reform were consistent with monetarism; new, neo, or old-fashioned Keynesianism; nominal income targeting; and inflation targeting. The record suggests that the reform was adopted when the FOMC became convinced that its earlier gradualist strategy using finely tuned interest rate moves had proved inadequate for fighting inflation and reversing inflation expectations. The new plan had to break dramatically with established practice, allow for the possibility of substantial increases in short-term interest rates yet be politically acceptable, and convince financial market participants that it would be effective. The new operating procedures were also adopted for the pragmatic reason that they would likely succeed.
\end{abstract}

Federal Reserve Bank of St. Louis Review, March/April 2005, 87(2, Part 2), pp. 187-235.

Do we have the wit and the wisdom to restore an environment of price stability without impairing economic stability? Should we fail, I fear the distortions and uncertainty generated by inflation itself will greatly extend and exaggerate the sense of malaise and caution... Should we succeed, I believe the stage will have been set for a new long period of prosperity. ${ }^{1}$

$$
\text { -Paul Volcker }
$$

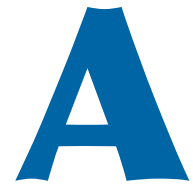
quarter-century after Paul Volcker's monetary policy reform in October 1979, the profound significance of restoring price stability for the nation's prosperity is widely recognized. Taming the inflation problem of the 1970s did set the stage for a long period of prosperity, as Volcker and many others had hoped. Over the past two decades, the nation has enjoyed greater price stability together with greater economic stability. Expansions have been uncommonly long and recessions relatively brief and shallow (Figure 1).

The centerpiece of the reform was the abandonment of federal funds rate targeting in favor of nonborrowed reserves targeting as the operating procedure for controlling the nation's money supply. This resulted in the unwelcome higher volatility of the federal funds rate (Figure 1) during a few years following the reform. In the prevailing environment of high and increasingly unstable inflation, however, small adjustments in the fed-

1 Volcker (1978, p. 61).

David E. Lindsey, before his retirement in 2003, was deputy director of the Division of Monetary Affairs at the Board of Governors of the Federal Reserve System. Athanasios Orphanides is an adviser in the Division of Monetary Affairs at the Board of Governors of the Federal Reserve System, a research fellow of the Centre for Economic Policy Research, and a fellow of the Center for Financial Studies. Robert H. Rasche is senior vice president and director of research at the Federal Reserve Bank of St. Louis. The authors thank Steve Axilrod, Norm Bernard, Carl Christ, Ed Ettin, and Allan Meltzer for comments and Stephen Gardner, April Gifford, and Katrina Stierholz for research assistance. The opinions expressed are those of the authors and do not necessarily reflect views of the Federal Reserve Bank of St. Louis or the Board of Governors of the Federal Reserve System.

(C) 2005, The Federal Reserve Bank of St. Louis. 
Figure 1

Real GDP Growth, Inflation, and the Federal Funds Rate
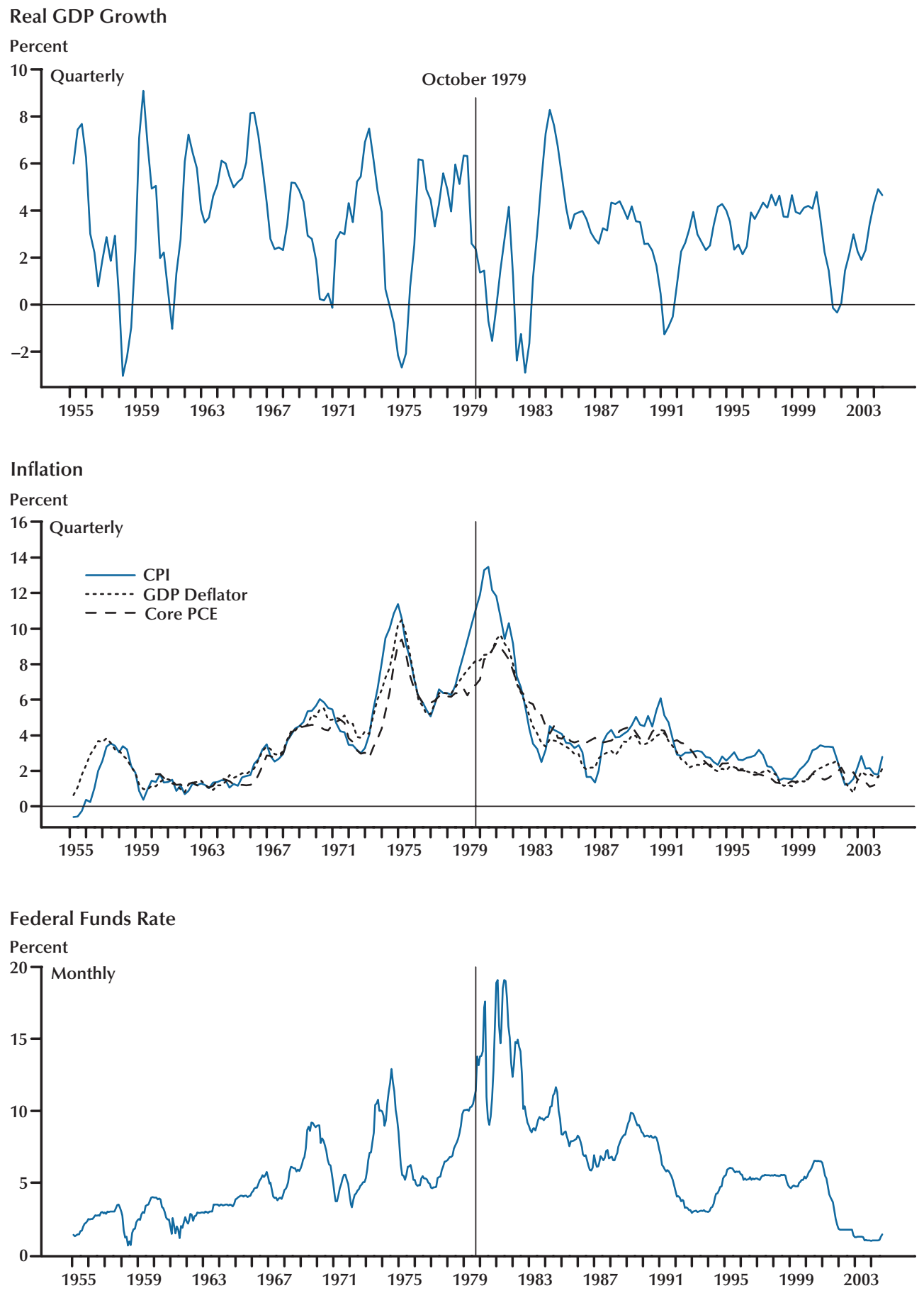
eral funds rate had proven woefully inadequate for reining in monetary growth.

The reforms of October run much deeper than the technical details that a mere switch in operating procedures would suggest. ${ }^{2}$ By the end of the 1970s, the policy framework of the Federal Reserve had inadvertently contributed to macroeconomic instability. The break in operating procedures facilitated a salutary reorientation of policy strategy, one focusing on the critical role of price stability for achieving and maintaining the System's objectives. This study offers a historical review of the monetary policy reform of October 6, 1979, and examines the reasons for and lessons from that experience in this broader context of the Federal Reserve's policy strategy.

The paper is organized in five sections. The first section, How It Happened, lays out the historical record from the start of 1979 through the spring of 1980, relying almost exclusively upon contemporaneous sources and with deliberately minimal editorial comment. An important new source for this historical description is the transcripts of Federal Open Market Committee (FOMC) meetings during 1979. These transcripts, which only recently became publicly available, prove especially valuable for assessing the reasoning behind FOMC actions. The second section, Why?, presents and discusses 12 reasons for the FOMC's adoption of the reform, approximately in order of increasing subtlety. The third section looks at the communications challenge presented to the Committee during this period, and asks whether "What We Have Here Is a Failure to Communicate!" Or Not! The fourth section asks Was Chairman Volcker... A Monetarist? A Nominal Income Targeter? A New, Neo, or Old-Fashioned Keynesian? An Inflation Targeter? or A Great Communicator? The final section concludes.

\section{HOW IT HAPPENED}

In the first half of 1979, the Board of Governors of the Federal Reserve System (BOG) under

\footnotetext{
2 For a description of the operating procedures prior to the reforms see Wallich and Keir (1979). See Axilrod (1981) and Lindsey (1986) for descriptions of the new operating procedures.
}

Chairman G. William Miller was short-handed and inexperienced, while the FOMC was deeply divided over the economic outlook, its primary policy objective, and its appropriate tactics. At the beginning of the year there were two vacancies on the Board, as Governor Jackson had resigned on November 17, 1978, and two days later Vice Chairman Gardner died. The two vacancies remained until one was filled by the appointment of Governor Rice on June 20, 1979.

Of the five members of the Board on January 31, 1979, Governor Wallich, who had taken office in March 1974, had the longest tenure. Two governors, Chairman Miller, and Governor Teeters, each had less than a year of service. The average tenure on that date was about 2.7 years, which was among the shortest on record (see Figure 2). ${ }^{3}$

At the year's first FOMC meeting in February, the Board staff indicated in the Greenbook that they expected real growth to slow, unemployment to rise, and, as a consequence of the increasing labor-market slack, the inflation rate to decline (BOG, 1979b, p. I-5). (Figure 3 shows the Greenbook forecasts through September and the staff's forecast prepared right after the October 6 reform.) Through May, the staff forecast for real growth and unemployment stayed essentially unchanged, but the inflation outlook deteriorated appreciably. ${ }^{4}$

Board members and Reserve Bank presidents initially were about evenly split on the outlook for continued real growth versus recession, but on balance they became increasingly pessimistic as time passed. At the February 1979 meeting at least six individuals indicated that they felt a recession during that year was possible. At the same meeting at least nine other individuals indicated that they agreed with the staff forecast of no recession, or thought that the outlook was for strong growth, or thought the most pressing issue was the inflation rate (FOMC, Transcript, 2/6/1979, pp. 10, 12, 22-23). But by the March meeting, the sentiment among the governors and presidents for continuing growth was already souring; by then

\footnotetext{
3 Governor Partee served on the senior staff of the Board of Governors for many years before his appointment to the Board, which began January 5, 1976. The terms of members of the Board expire on January 31 of even-numbered years.

4 See Kichline (1979a,b,c).
} 
Figure 2

\begin{abstract}
Average Tenure of Federal Reserve Board Members (as of January 31 of Year Shown)
\end{abstract}

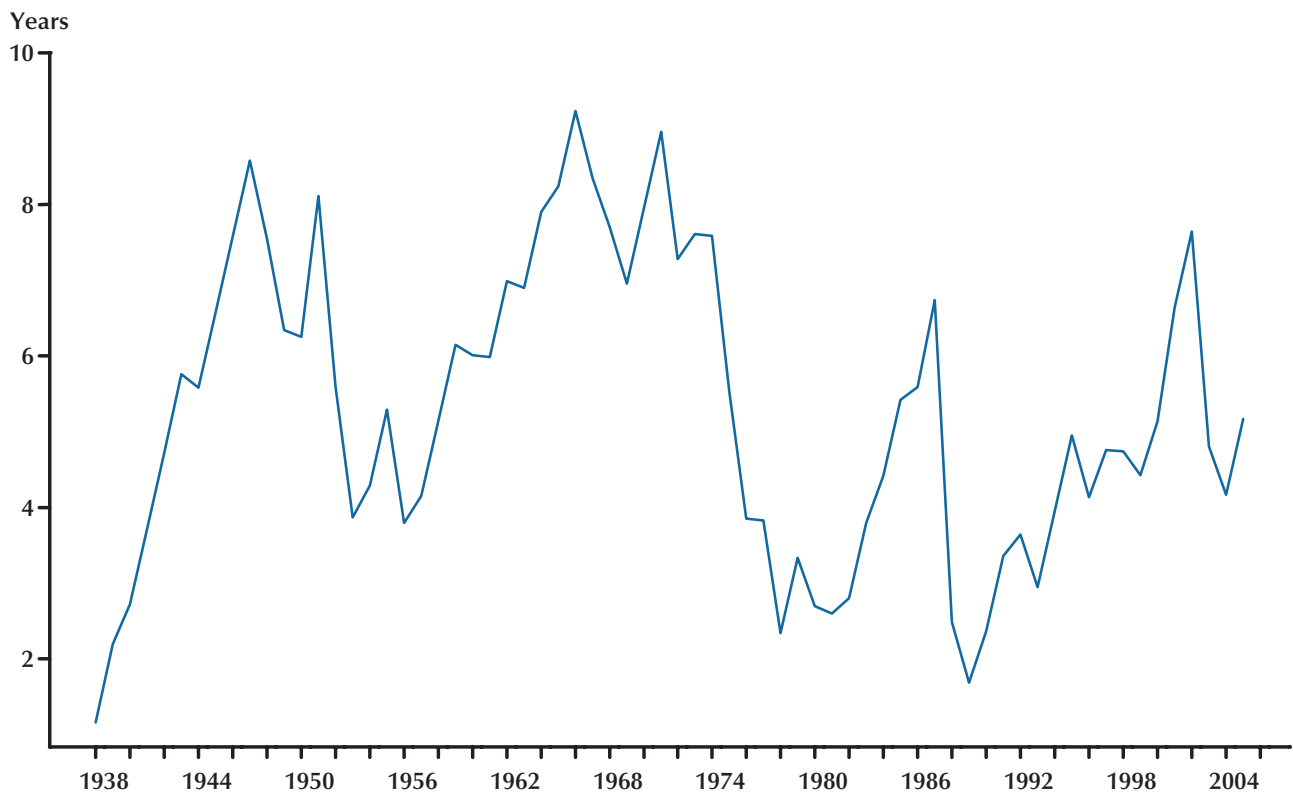

at least nine individuals predicted a recession before the end of the year. By the May meeting, at least eight individuals felt that the economy either already was in recession or close to a cyclical peak.

In early July, the Greenbook assessed that a recession had already started by the second quarter, and it was projected to persist to the end of the year. The Board apparently held a similar view, as the July 17 Monetary Policy Report indicated that the projection of Board members for real gross national product (GNP) growth over 1979 was -2 to $-1 / 2$ percent (BOG, 1979a, p. 76). All the while, inflation was worsening further, in part due to the rapid increase in energy prices. Private forecasts of economic activity were no less pessimistic. Indeed, the Blue Chip consensus forecast pointed to a recession even before the staff did, starting in May. Such forecasts of recession accompanied by increasingly virulent inflation remained a recurrent theme both in the Greenbook and in the Blue Chip consensus forecasts for the remainder of the year.
The deteriorating inflation situation and the increasing pessimism about prospective real growth produced different opinions at the FOMC table as to the appropriate focus of policy. One group was quite vocal that priority had to be assigned to addressing inflation; a second group was equally vociferous that priority instead should be given to mitigating the risk of economic weakness. The conflict posed a difficult situation for Chairman Miller, who appears to have viewed his role as that of discovering a consensus among the FOMC principals. His mode of operation was to collect statements on the wording of a directive (in terms of growth rates of M1 and M2 and a range for the federal funds rate) and then to float a "trial balloon" to see how much support it garnered (FOMC, Transcript, 3/20/1979, pp. 31-32). At some meetings Chairman Miller did not even state his own view of the economic outlook or an appropriate wording for the directive.

Dissents from the directive were common, even numerous, at some of the meetings in the first half of 1979. Four members dissented at the March 


\section{Figure 3}

\section{Evolution of Greenbook Forecasts During 1979}
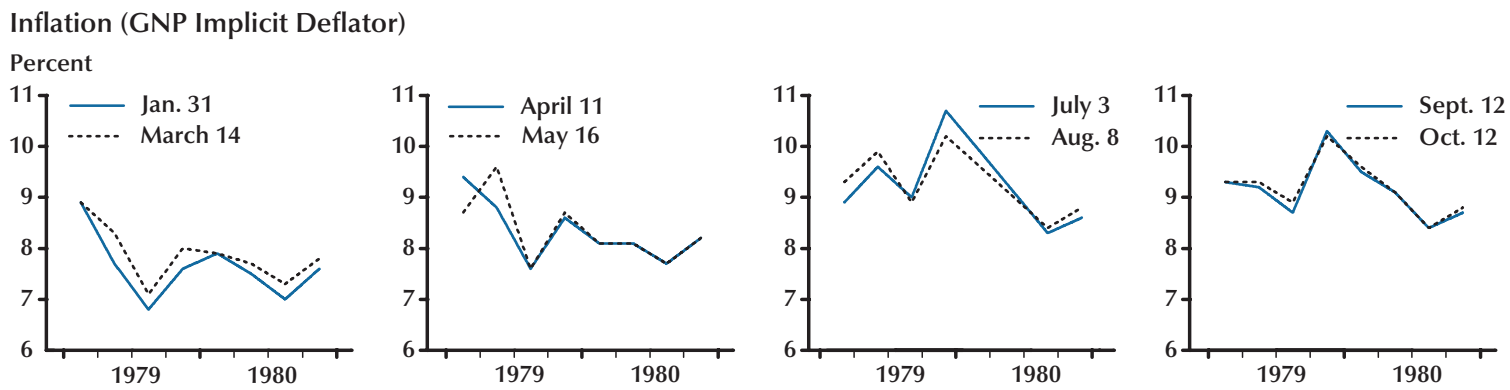

Real GNP Growth
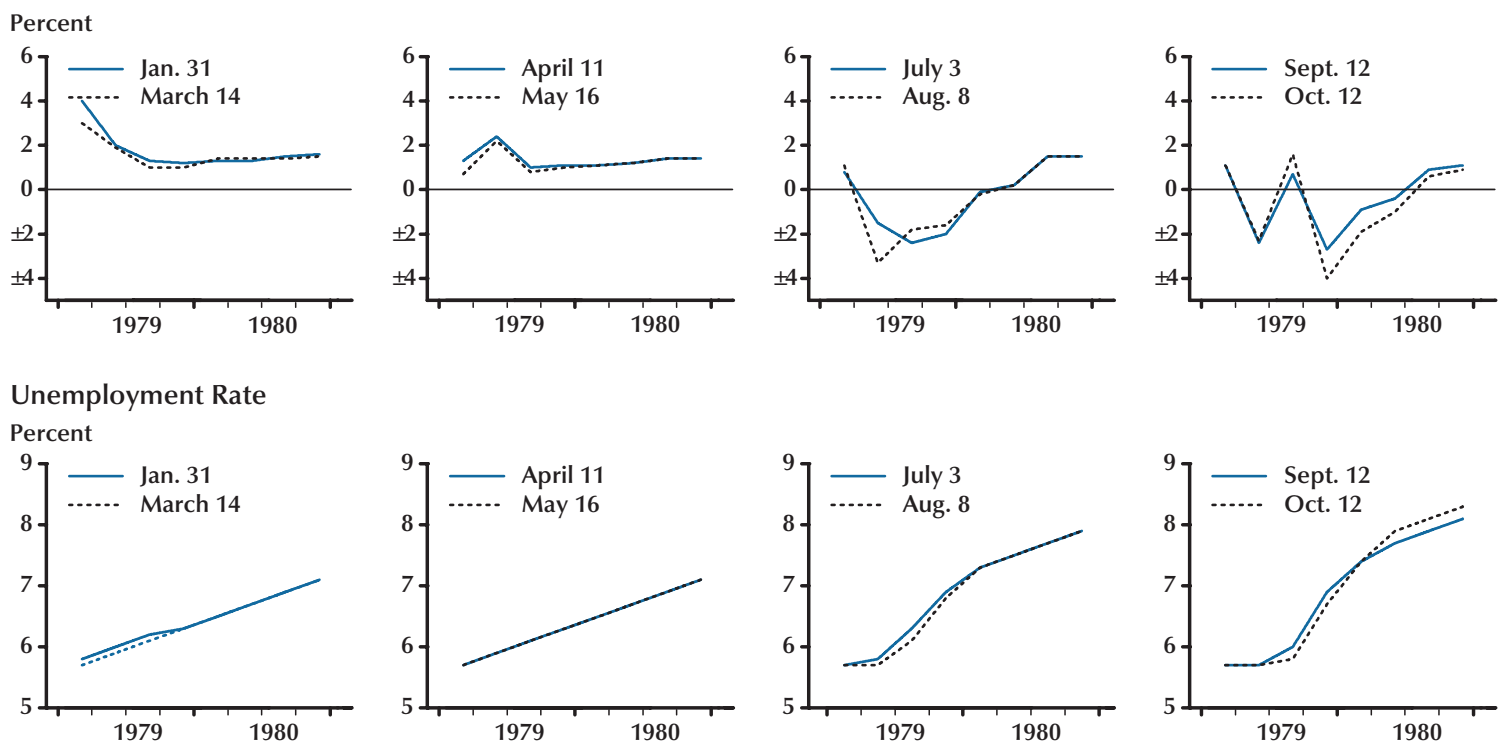

meeting because they favored tighter policyafter only one dissent, also in that direction, at the February meeting (BOG, 1979a, pp. 142-43). Three dissents from the directive occurred in April, all toward tighter policy, and three dissents again were recorded in May-two for easier and one for tighter policy (BOG, 1979a, pp. 156, 165). The conference calls on June 15 and July 27 elicited one dissent each, the first in favor of a tighter policy stance and the second in favor of an easier one (BOG, 1979a, pp. 166, 178). Only at the July meeting was the directive adopted unanimously (BOG, 1979a, p. 178). Based on his comments, Chairman Miller seemed frustrated by the dissents.
An ongoing issue during the first half of 1979 was whether the FOMC should frame the operating paragraph of the directive to the Manager for Domestic Operations, System Open Market Account, in terms of a "monetary aggregates" or a "money markets" objective. This nuance was a significant issue in the minds of many FOMC participants. Surprisingly, considering the extent of the internal discussion devoted to this issue, the only explicit definition or explanation of the terminology that we have been able to find is in the staff recommendations for alternative wording of the directive that appear in the 1979 Bluebooks. For example, in the Bluebook for the February 
1979 FOMC meeting the staff suggested both a "monetary aggregates emphasis" and a "money market emphasis" as alternative wording for the directive. The difference seems to be only a single phrase. The suggested wording with the monetary aggregates emphasis was this:

If, with approximately equal weight given to M1 and M2, their growth rates appear to be significantly above or below the midpoints of the indicated ranges, the objective for the funds rate is to be raised or lowered in an orderly fashion within its range. (BOG, 1979c, p. 20)

The suggested wording for the money market emphasis was this:

If, with approximately equal weight given to M1 and M2, their growth rates appear to be close to or beyond the upper or lower limits of the indicated ranges, the objective for the funds rate is to be raised or lowered in an orderly fashion within its range. (BOG, 1979c, p. 20)

The distinction seemed to have hinged on whether the Manager was to react to growth of the aggregates within the specified ranges or only when the growth of the aggregates approached or went outside the stated ranges. But, in practice, the federal funds rate fluctuated within rather narrow ranges under either directive. On the basis of this distinction, all of the directives from the February through September 1979 FOMC meetings, except for that adopted at the March FOMC meeting, were "money market directives."

As to the actual policy stance, Chairman Miller's tenure in 1979 included only minor tightenings-gauged by the FOMC's funds rate objective. Two occurred on conference calls and without formal FOMC votes. They were in line with directive instructions to make small funds rate adjustments up (or down) within a specified range to resist emerging faster- (or slower-) thanspecified growth in the monetary aggregates. The first took place on April 27, when the funds rate objective went from a range of 10 to $10^{1 / 8}$ percent to $10^{1 / 4}$ percent, and the second on July 19 , when the FOMC raised the target to $10^{1 / 2}$ percent. On the next day, the Board unanimously voted to hike the discount rate $1 / 2$ percentage point to 10 percent. Miller's departure to the Treasury was announced on July 19 and took place when Chairman Volcker was sworn in on August 6. When Miller went to the Treasury, the Trading Desk, acting between Committee meetings in accord with directive instructions from the FOMC, was pursuing an increased federal funds rate objective of $10^{5} / 8$ percent or a shade higher, compared with 10 percent or slightly higher as the year began.

Vice Chairman Volcker's impression of emerging macroeconomic problems remained remarkably constant during G. William Miller's chairmanship in 1979. Such a conclusion can be drawn from Volcker's comments at the February, March, April, and May meetings of the FOMC.

Vice Chairman Volcker...I continue to feel that we could have a recession, but it's by no means certain. I wouldn't rule one out, by any means, in the second half of the year. But in terms of the recession outlook itself, I think the number one problem continues to be the concern about the price level. The greatest risk to the economy, as well as [to actual] inflation, is people having the feeling that prices are getting out of control. (FOMC, Transcript, 2/6/1979, p. 10)

Vice Chairman Volcker...I think the odds are better than 50/50 that we're going to run into a recession by [year-end], and I've thought that for some time...Essentially, I think we're in retreat on the inflation side; if there's not a complete rout, it's close to it. And in my view that poses the major danger to the stability of the economy as we proceed. (FOMC, Transcript, 3/20/1979, pp. 9-10)

Vice Chairman Volcker...And [inflation] clearly remains our problem. In any longerrange or indeed shorter-range perspective, the inflationary momentum has been increasing. In terms of economic stability in the future that is what is likely to give us the most problems and create the biggest recession. And the difficulty in getting out of a recession, if we succeed, is that it conveys an impression that we are not dealing with inflation. I'm afraid that is the impression that we are conveying. We talk about gradually decelerating the rate of inflation over a series of years. In fact, it has been accelerating over a series of years and hasn't yet shown any signs of reversing. (FOMC, Transcript, 4/17/1979, p. 16) 
Vice Chairman Volcker...I'm impressed by the degree that inflation is now built into thinking in terms of the business outlook. I'm also impressed-the supporting factor-by the degree with which capacity problems and backlogs exist...Frank Morris said that we can't casually assume the recession will be mild. I suppose we can't casually assume it, although it looks that way to me now-if we're going to have one. But we can't always be looking at the worst. If we're going to balance these risks of inflation and recession we have to run not too scared that the recession is going to be worse than we expect. So it is a question of bringing about a balance. (FOMC, Transcript, 5/22/1979, p. 22)

While vice chairman, Volcker expressed skepticism about the ability of economists to make accurate forecasts.

Vice Chairman Volcker...When I look at the outlook for real GNP, it does seem to me that the staff forecast of six quarters of approximately 1 percent growth in GNP per quarter is inherently improbable. I don't think that has ever happened.

Chairman Miller. Plus or minus 3 percent.

Vice Chairman Volcker. That is precisely the difficulty. The reason they have come up with this forecast is that one doesn't know whether the 3 percent error will in fact be plus or minus. I must say in talking about projection errors that I am much more concerned about the persistent errors in the projections of the inflation rate than I am about the recent errors in the projections of the monetary aggregates. The inflation projections have been consistently on the low side. And I'm not just talking about the staff's projections; I think that has been true of most forecasters. (FOMC, Transcript, 4/17/1979, pp. 15-16)

Vice Chairman Volcker...I'm not inclined to raise the question of whether the staff have overestimated the rate of price increase; I doubt that that's the case. (FOMC, Transcript, 7/11/1979, p. 7)

Given his view of the outlook for inflation, despite more hopeful forecasts by others, Volcker advocated monetary policy tightening in the first part of the year before the policy move in that direction in late April. In February he first voted in a straw poll against standing pat before grudgingly switching his vote in the end. However, he dissented from that policy stance at both the March and April meetings.

Vice Chairman Volcker...I think we are at a critical point in the inflation program, with the tide against us. If we don't show any response at all, we are giving an unfortunate signal in my judgment. I believe those concerned about inflation would find no response during this period almost inexplicable in terms of what we say regarding our worries about inflation...I do think we need to make some move in recognition of what has been happening on the inflation front. And I think its good for the stability of the economy in the long run. (FOMC, Transcript, 3/20/1979, pp. 10, 28)

Vice Chairman Volcker...We may be one month closer to a recession than we were last month and I think we are late [in tightening], but I still am of the view that some greater degree of restriction would be more appropriate than the reverse [and] more appropriate than standing still. (FOMC, Transcript, 4/17/1979, p. 16)

His hawkish perspective at the March and April meetings did not, however, stem mainly from recent rapid money growth-which at that time in fact was running far below expectations. ${ }^{5}$

Vice Chairman Volcker...I don't think that \{money\} target itself, though written in our records, is written in heaven, given all the uncertainties that we had when we set it... $\{$ T\}he exact level of the aggregates isn't quite as important to me as the movement on the funds rate. I'd like to make some gesture there immediately. (FOMC, Transcript, 3/20/1979, pp. 28-29)

Vice Chairman Volcker...I sit here listening to all this about the aggregates and it seems to me that the only reasonable conclusion is not to put much weight on the aggregates. We see

5 Light editing that actually appears in the official transcripts is shown here with brackets, [ ]. Further editing we have done for this paper is shown with braces, \{\} . 
relationships that go way out of the range of historical experience. We haven't any idea of the validity of the forecast [for the monetary aggregates], I'm afraid, and the combination of those two events does not make me want to linger over the aggregates. (FOMC, Transcript, 4/17/1979, p. 15)

By the time of the May meeting, though, money growth had become more normal, and he was ready to upgrade the role of the aggregates in policymaking.

Vice Chairman Volcker...As I thought about what to do, I arrived at the same conclusion that Steve did up to a point-that maybe for lack of anything better we should go back and look at the aggregates a bit...I was thinking of widening the range mostly in the downward direction rather than widening it on the up side. But I do think that's a reasonable approach as we watch both the aggregates and the business news in the next six weeks. (FOMC, Transcript, 5/11/1979, p. 22)

Volcker's hawkish views were well known outside the Federal Reserve as well as inside at the time President Carter interviewed him for Federal Reserve Chairman in July. In Volcker's recollection of the interview, "I told him the Federal Reserve was going to have to be tighter and that it was very important that its independence be maintained." Although Volcker thought that these views might preclude his nomination as Chairman, the President proved him wrong despite the opposition of some of his advisers (Treaster, 2004, pp. 61-62). President Carter's nomination of Paul Volcker to replace G. William Miller as chairman of the Federal Reserve Board was announced on July 25 . The exchange value of the dollar steadied on this news, but in a July 27 conference call that was not transcribed, the FOMC voted to raise not the actual funds rate target but rather the upper limit of its allowable range to $10^{3} / 4$ percent, making a new range of $10^{1 / 2}$ to $10^{3 / 4}$ percent, owing to strong growth in the aggregates (FOMC, 1979b, pp. 1-2).

Volcker's nomination enjoyed wide support across the political spectrum, and his confirmation hearing on July 30 was relatively uneventful. At the hearing Volcker reiterated his well-publicized views in favor of curbing inflation and stressed that "if we're going to have price stability" it was "indispensable" to bring down the growth of monetary aggregates (U.S. Senate, 1979, p. 12). Volcker took the oath of office on August 6, and he presided over the August 14 FOMC meeting. At that meeting, the FOMC continued its recent turn toward firming. With two dissents-one in favor of a smaller, and one in favor of a larger, move-the FOMC raised the funds rate objective from $10^{5} / 8$ percent or a shade higher to 11 percent. Chairman Volcker's thinking can be gleaned from a selection of his comments.

Chairman Volcker...It looks as though we're in a recession; I suppose we have to consider that the recession could be worse than the staff's projections suggest at this time... When we look at the other side, I don't have to talk much about the inflation numbers...And when I look ahead, nobody is very optimistic about the inflation picture...When I look at the past year or two I am impressed myself by an intangible: the degree to which inflationary psychology has really changed...\{I\}t would be very nice if in some sense we could restore our own credentials and [the credibility] of economic policy in general on the inflation issue. (FOMC, Transcript, 8/14/1979, pp. 20-22)

He proposed "some gesture" at that meeting, though the time did not seem ripe for a major move or any procedural change.

Chairman Volcker...\{W\}e don't have a lot of room for maneuver and I don't think we want to use up all our ammunition right now in a really dramatic action; I don't see that the exchange market or anything else really requires that at the moment. Certainly dramatic action would not be understood without more of a crisis atmosphere than there is at the moment. Ordinarily I tend to think we ought to keep our ammunition reserved as much as possible for more of a crisis situation where we have a rather clear public backing for whatever drastic action we take. (FOMC, Transcript, 8/14/1979, pp. 22-23)

On August 16, the Board voted unanimously to increase the discount rate $1 / 2$ percentage point 
to $10^{1 / 2}$ percent. In response to continued strong aggregates growth and dollar weakness, the Desk subsequently raised the funds rate objective in two steps (in accordance with directive instructions) to $11^{3} / 8$ percent by the end of August, an operating objective that lasted until the September 18 FOMC meeting. The Board considered additional requests to raise the discount rate in late August and early September but appeared deeply divided on the need for such increases. In late August, the Board voted against such raises. Then, in early September it tabled multiple requests for additional action, effectively postponing a decision until after the FOMC meeting scheduled for September 18 (BOG, Minutes, 9/7/1979, p. 4; 9/14/1979, p. 3).

Early in the September 18 meeting, President Roos of the Federal Reserve Bank of St. Louis raised the question of whether the FOMC's operating procedures should be reexamined. Chairman Volcker indicated that the Committee's decision that day should be within the traditional approach but that the question should be reassessed soon by the Committee.

Mr. Roos...[Given] your statements, which I think are great, that we're never going to accomplish our ultimate goal until we achieve some discipline in terms of monetary growth, couldn't we discuss these issues again? Maybe I am out of order to raise this now, but couldn't there be a discussion again of whether or not our traditional policy of targeting on interest rates, in spite of the possible adverse consequences in terms of money growth, [is appropriate]? Shouldn't this be given another look in view of everything you've said and in view of the less than happy experience that the FOMC has had over the past years in achieving its goals of stability in terms of the inflation problem? Shouldn't we take a look at this in some way?

Chairman Volcker. My feeling would be that you're not out of order in raising that question, Mr. Roos. We would be out of order in having an extended discussion of it today, because I don't think we're going to resolve it. I presume that today, for better or worse, we have to couch our policy in what has become the traditional framework. But I think it is a very relevant question, which has come up from time to time, and I think we should be exploring it again in the relatively near future. And I would plan to do so. (FOMC, Transcript, 9/18/1979, pp. 13-14)

Later at that FOMC meeting, Chairman Volcker, in laying out the policy choice, again noted both horns of the existing dilemma.

Chairman Volcker...There is a very strong possibility of recession on the one side. We've had that possibility for almost six months now and we still have the unemployment rate at a level that some consider to be the natural rate. I don't know whether it is or it isn't, but we had a lot of discussion earlier, which may be reflected in some of the comments about labor markets still being fairly tight. And, obviously, we have inflation as strong as ever. We have a difficult timing problem. Difficult or not we have a timing problem if the business outlook develops more or less as projected, in that we don't have a lot of flexibility-at least flexibility in a tightening direction-in terms of what we can do in the midst of a real downturn...But we are in a rather crucial period in terms of how much the probably deteriorating inflationary expectations now get built into the wage structure...I also share the view that has been quite widely expressed that we have to show some resistance to the growth in money. (FOMC, Transcript, 9/18/1979, pp. 33-34)

He recommended only limited further tightening.

Chairman Volcker...As I listened, among the voting members of the Committee at least, I think there was a majority desire-but clearly not unanimous-to make a little move on the federal funds rate. So I would propose 11-1/2 percent on that at this point. I am not particularly eager to make a major move now or in the foreseeable future, so I would suggest that we put a band around that of 11-1/4 to 11-3/4 percent, which ought to [result in a] reconsideration before a very major step on the funds rate. (FOMC, Transcript, 9/18/1979, p. 35)

The vote elicited eight assents but four dissents; the dissents included Governor Rice on the 
dovish side, but three of them came from hawksPresidents Balles and Black and Governor

Coldwell-who were disappointed at the lack of sufficiently forceful action. After the conclusion of the FOMC meeting, the Board met to consider the pending requests for raising the discount rate. The Board continued to be divided on the desirability of such action. Members supporting the increase pointed to the virulence of inflation and inflationary expectations, while members opposing the action emphasized the weakening in economic activity and the lagged effects of monetary policy. In the end, the Board split nearly evenly in approving a $1 / 2$-percentage-point discount rate hike to 11 percent: The vote was four to three, with the dissenting votes all on the dovish sideGovernors Partee, Rice, and Teeters.

As usual, the vote on the discount rate, with the three dissents toward more dovish policy, became known right away after the announcement of the discount rate change. By contrast, neither the FOMC's tightening action that morning nor the hawkish sentiment reflected in the three dissents in favor of further tightening was released immediately. Without this information, the dovish dissents on the discount rate had a dramatic and arguably misleading effect on perceptions regarding the policy intentions of the FOMC. The Board action engendered the perception that the Federal Reserve's resistance to inflationary forces would be insufficient and discomfited financial markets. The press interpreted the vote thusly:

Many money market analysts have been expecting the FOMC to seek to tighten credit again in an effort to slow down sharp increases in the money supply...However, the split vote, with its clear signal that from the Fed's own point of view interest rates are at or close to their peak for this business cycle, might forestall any more increases in market interest rates. (Berry, 1979, A1)

This division indicates that Mr. Volcker's drive for a restrictive monetary policy may encounter increasing opposition within the seven-member board. (Wall Street Journal [WSJ], 1979b, p. 2)

[T] he vote left uncertain whether Paul A. Volcker, who became Federal Reserve chairman early in August, could continue to command a majority for his high-rate policies. The split was seen as indicating a fundamental division within the board over whether inflation remains a more pressing problem than recession...

"A 4-3 split is significant because it means Volcker will have to sit harder on the liberal governors," Jeffrey A. Nichols, vice president and chief economist of the Argus Research Corporation, said. "The Chairman will have to be tough to keep the other members under control."...

One banker said she thought the failure of the board yesterday to cite inflation or the growth of the money supply, but merely to note technical factors, could indicate a compromise with governors who were becoming more concerned about recession than inflation. "It might mean we have the beginnings of a dovish voting group," she added. (Bennett, 1979, p. A1)

Some dealers reasoned that the Federal Reserve Board's 4-to-3 split vote on the discount rate increase meant the central bank would have difficulty in making further moves to restrict the growth of money and credit...

"The Reserve Board vote," one municipal bond dealer said, "makes me think that this is as much of a push toward higher rates as we're going to get for a while. I [don't] think that 4to-3 vote sat very well with a lot of traders today." (Allen, 1979, p. D9)

The 4-to-3 split gave rise to speculation that the Federal Reserve was unlikely to drive interest rates still higher. (Cowan, 1979, p. 1)

The relatively small increase in the funds target reflects "a growing split within the Fed's policymaking circle," according to David Jones, an economist for Aubrey G. Lanston \& Co. He reasoned that with the economy losing steam some Fed officials want a pause in credit tightening while others contend that further moves are necessary to battle inflation. (WSJ, 1979e, p. 5)

The events of September 18 had a swift destabilizing effect on markets that set the tone for developments over the following three weeks. Commodity markets, in particular, became 


\section{Figure 4}

\section{Commodity Futures Prices}

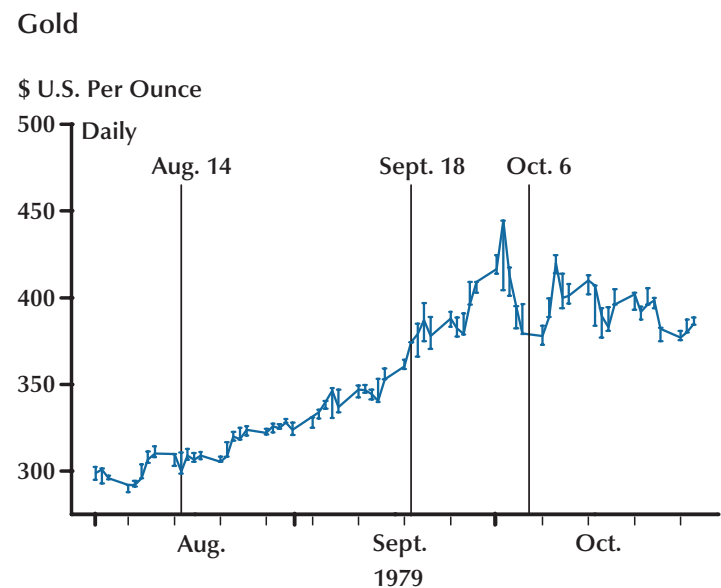

Copper

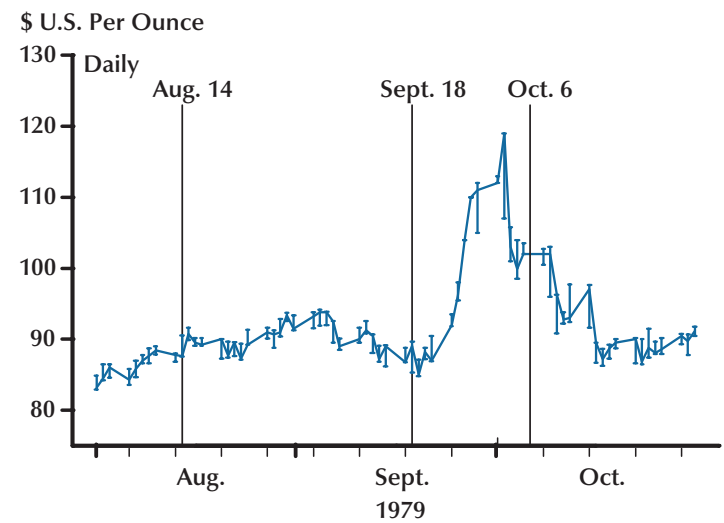

Silver

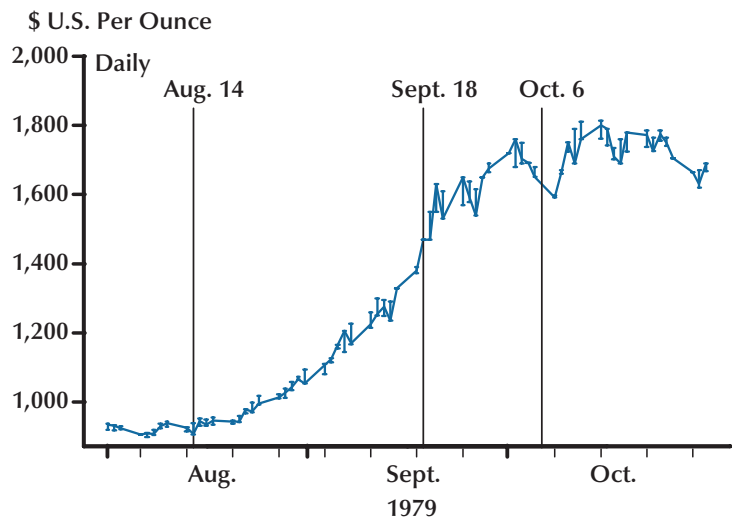

Platinum

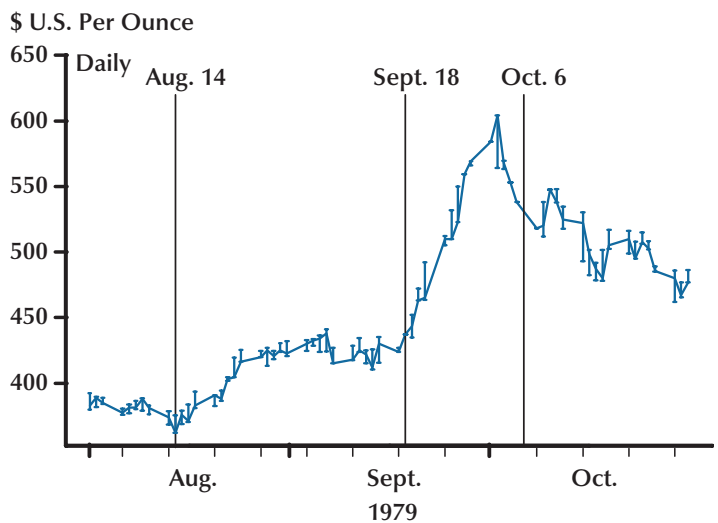

NOTE: For each day, the graphs show the opening price and high/low trading range during the day. Vertical lines denote FOMC meetings.

extremely volatile, alarming policymakers. Developments in commodity markets during this period are illustrated in Figure 4, which shows the daily futures prices of the December 1979 contracts for gold, silver, and copper and the January 1980 contract for platinum. The vertical lines in each panel indicate the dates of FOMC meetings. The continuous line designates the opening price each day, while the high-low lines denote the intraday range of price fluctuation. Gold and silver futures prices rose steadily between the August and September FOMC meeting dates, but with the exception of a few days, the intraday volatility was little changed from earlier in the summer. Copper futures were stable during this period, and, though platinum prices rose, they merely returned to mid-year levels.

The behavior of prices in these markets changed dramatically in the days after the discount-rate announcement. Gold and silver prices continued moving up, and intraday volatility increased substantially. Copper and platinum futures prices rose rapidly, also with substantial intraday volatility. Prices on all four futures contracts reached a peak on October 2 and retreated sharply for the next several days.

The price developments in these markets were 
noted regularly in the press. A sample of this commentary, which uniformly interpreted these developments as evidence of hedging against inflation, follows.

For gold's rise, analysts had been citing the metal's traditional allure during times of inflation and general global unease. (WSJ, 1979a, p. 3)

With a leap that would have been dismissed before as inconceivable, the price of gold soared a record $\$ 24$ an ounce in London, to another high of $\$ 375.75$, and then jumped an additional $\$ 6.25$ in later dealings in New York.

Although he [a Treasury official] said he didn't believe gold's surge was "directed particularly against the dollar," he said the jump was "disturbing" and could cause a "widespread psychological reaction...a lack of confidence in our ability to turn inflation around." (WSJ, 1979c, p. 8)

Mr. Miller told the National Conference of State Legislatures that there has been a "speculative trend" in the gold market as people bought gold as an inflationary hedge...

Another Treasury official called the current gold rush "a symptom of growing concern about world-wide inflation." Lisle Widman, the Treasury's deputy assistant secretary for international monetary affairs added that "the message we would draw is that governments around the globe need to redouble efforts to curb inflation."(WSJ, 1979d, p. 2)

In the commodity markets, nervous speculators sent futures prices through wild gyrations. At first, prices rose sharply as the recent bout of gold and silver fever spread to markets for other raw materials. Gold, silver, copper, platinum and sugar all rose to new highs in early dealings, presumably because inflation-wary speculators continued to dump dollars in favor of commodities...

But then came the rumors that the U.S. might be planning a major new dollar-support program. On the theory that fighting inflation to save the dollar might depress commodity prices, speculators began selling, and many futures prices skidded the maximum permitted in a single day of trading. By the end of the day, however, most prices recovered somewhat when the rumors hadn't been substantiated, and many traders admitted to considerable confusion about the day's developments. (WSJ, 1979f, p. 1)

A few days after the discount-rate vote, Governor Partee spoke to the Money Marketeers in New York. Their harsh questions converted him on the spot from a dove to a hawk (Greider, 1987, p. 85).

As September drew to a close, the crisis that Chairman Volcker spoke of at the August FOMC meeting evidently had arrived, and the need for a dramatic monetary policy announcement had become compelling. The Chairman became increasingly convinced that such action should include a change in operating procedures deemphasizing the federal funds rate in favor of reserves as an operating instrument. He asked Stephen Axilrod, Economist for the FOMC, and Peter Sternlight, Manager for Domestic Operations, System Open Market Account, to prepare a background memorandum for the FOMC outlining the general features of such a proposed new approach. He also discussed changing the operating procedures with the other members of the Board to garner their support early on (Greider, 1987, pp. 105-118; Volcker and Gyohten, 1992, pp. 167; Treaster, 2004, p. 150; FOMC, Transcript, 10/5/1979, p. 1).

In his discussions with the Board members, Fred Schultz, the Board's vice chairman, lined up foursquare behind the Chairman, as would usually be the case in decisions to come, in this instance in his support for the Chairman's call for dramatic monetary-policy action. The three Board members who had voted against the discount rate hike, Teeters, Rice, and Partee, also supported the change. As will be discussed in more detail below, they liked the automaticity of the reserves-based technique in that the FOMC did not choose, and thus could not be identified as having chosen, the specific level of the funds rate. The two hawks, Wallich and Coldwell, were philosophically opposed to money and reserve targeting as unreliable and as removing too much central bank judgment from the monetary policy process, but they were willing to go along with it 
if necessary to get FOMC support for a substantially tighter policy stance. According to Greider,

Wallich did not argue much. "I was not sure people would do it my way," he said. "It was probably wise to use a method that produced a consensus for tightening." (Greider, 1987, p. 113)

On September 29, Chairman Volcker left for the annual International Monetary Fund (IMF) meeting, which was in Belgrade that year. ${ }^{6}$ On the plane flight to Europe, the Chairman took the opportunity to brief two top administration officials, G. William Miller, who was now Secretary of the Treasury, and Charles Schultze, chairman of the Council of Economic Advisors. They were not enthusiastic about the idea of new procedures, and in coming days they made their solidifying views known to Volcker. Moreover, in their subsequent conversations with President Jimmy Carter, the President may have voiced similar concerns to them. But Chairman Volcker considered it significant that the President never directly expressed this disapproval to him in person or otherwise (Volcker and Gyohten, 1992, pp. 168-69).

On his trip abroad, Chairman Volcker also sought the counsel of various trusted foreign leaders and central bankers, including Germany's Helmut Schmidt and Otmar Emminger. Their comments only reinforced his intention to move ahead. When his participation was no longer required at the IMF meetings, he returned early to the United States (Volcker and Gyohten, 1992, p. 168).

Chairman Volcker arrived in Washington on Tuesday, October 2, with his ears still resonating with strongly stated European recommendations for stern action to stem severe dollar weakness on exchange markets. His unexpectedly early return fueled market rumors that action dealing with the crisis might be imminent. This had a stabilizing effect on commodities markets, with futures markets opening lower on October 3, retracing some

\footnotetext{
6 In addition to Chairman Volcker, the three previous Federal Reserve Chairmen were at the Belgrade meeting. Chairman Miller was attending as Treasury secretary. And Chairman Martin was to introduce Chairman Burns who was giving the Per Jacobsson lecture that year. Burns took the occasion to deliver his remarkable "The Anguish of Central Banking," which we return to later on.
}

of their sharp increases of the previous several days (Figure 4).

The next regularly scheduled meeting of the FOMC was to take place on October 16, 1979, two weeks after Volcker's return from Europe. However, likely in light of the urgency of the situation after September 18, the Chairman instead decided to convene a special FOMC meeting earlier in the month. The special meeting, scheduled in secret and on very short notice, was to take place on Saturday, October 6, in Washington.

Few new governmental data were released in the three weeks after September 18 that could have provoked a sense of urgency about significant policy action. Table 1, reproduced from the Greenbook from October 12, 1979, shows the dating of various statistical releases tracked by the staff between September 18 and October 5. The only data published after that starting date but before Volcker left for Belgrade were for the consumer price index (CPI) and housing starts in August. To be sure, the annualized one-month core CPI inflation rate in August exceeded 12 percent, up substantially from the 8.7 percent July core CPI inflation rate available at the September FOMC meeting. But this information, while unpleasant, did not seem to be the source of the alarm, as will be seen from Chairman Volcker's interpretation of these figures on October 6.

On the morning of Thursday, October 4, two days before the planned Saturday meeting, the Board met in its Special Library to discuss the possible monetary policy actions under consideration. According to the Minutes of the meeting:

$[\mathrm{O}]$ ne member of the Board referred to the outburst of speculative activity in the gold market, which appeared to be spilling over into other commodity markets as well, and to the very sensitive conditions in domestic financial and dollar exchange markets. He also noted that inflationary sentiment appeared to be intensifying as data on price increases continued to worsen. Against this background, the staff had been directed to prepare memoranda on a package of possible actions designed to show convincingly the Federal Reserve's resolve to contain monetary and credit expansion in the U.S., to help curb emerging speculative excesses, and thereby to dampen inflationary 


$$
I-8
$$

October 12,1979

SELECTED DOMESTIC NONFINANCIAI DATA AVAILABLE SINCE PRECEDING GREENBOOK

(Seasona1ly adjusted)

\begin{tabular}{|c|c|c|c|c|c|c|}
\hline & \multicolumn{3}{|c|}{ Latest Data } & \multicolumn{3}{|c|}{ Percent Change from } \\
\hline & Period & $\begin{array}{c}\begin{array}{c}\text { Release } \\
\text { Datee }\end{array} \\
\end{array}$ & Data & $\begin{array}{c}\text { Preceding } \\
\text { Pertod }\end{array}$ & $\begin{array}{l}\text { Periods } \\
\text { Earlier }\end{array}$ & $\begin{array}{c}\text { Year } \\
\text { earlier }\end{array}$ \\
\hline & & & & & At annual & rate) \\
\hline $\begin{array}{l}\text { Civilian labor force } \\
\text { Unemployment rate ( }(x) 1 / \\
\text { Insured unemployment rate (\%) } 1 / \\
\text { Nonfarm employment, payroll (mil.) } \\
\text { Manufacturing } \\
\text { Nonmanufacturing }\end{array}$ & $\begin{array}{l}\text { Sept. } \\
\text { Sept. } \\
\text { Sept. } \\
\text { Sept. } \\
\text { Sept. } \\
\text { Sept. }\end{array}$ & $\begin{array}{l}10-5-79 \\
10-5-79 \\
10-5-79 \\
10-5-79 \\
10-5-79 \\
10-5-79\end{array}$ & $\begin{array}{r}103.5 \\
5.8 \\
3.0 \\
89.9 \\
21.0 \\
68.9\end{array}$ & $\begin{array}{l}5.2 \\
6.0 \\
3.1 \\
1.8 \\
1.4 \\
1.9\end{array}$ & $\begin{array}{r}3.8 \\
5.6 \\
2.8 \\
1.0 \\
-1.5 \\
1.8\end{array}$ & $\begin{array}{l}2.5 \\
5.9 \\
3.4 \\
3.2 \\
2.3 \\
3.5\end{array}$ \\
\hline $\begin{array}{l}\text { Private nonfarm: } \\
\text { Average weekly hours }(\mathrm{hr} \cdot) \underline{1} \\
\text { Hourly earnings }(\$) \underline{1} / \\
\text { Manufacturing: }\end{array}$ & $\begin{array}{l}\text { Sept. } \\
\text { Sept. }\end{array}$ & $\begin{array}{l}10-5-79 \\
10-5-79\end{array}$ & $\begin{array}{l}35.6 \\
6.25\end{array}$ & $\begin{array}{l}35.6 \\
6.22\end{array}$ & $\begin{array}{l}35.6 \\
6.13\end{array}$ & $\begin{array}{l}35.8 \\
5.78\end{array}$ \\
\hline $\begin{array}{l}\text { Average weekly hours (hr.) } 1 / \\
\text { Unit labor cost }(1967=100)\end{array}$ & $\begin{array}{l}\text { Sept. } \\
\text { Aug. }\end{array}$ & $\begin{array}{l}10-5-79 \\
9-28-79\end{array}$ & $\begin{array}{r}40.0 \\
176.5\end{array}$ & $\begin{array}{r}40.1 \\
8.9\end{array}$ & $\begin{array}{r}40.1 \\
7.4\end{array}$ & $\begin{array}{r}40.5 \\
8.2\end{array}$ \\
\hline $\begin{array}{l}\text { Industrial production }(1967=100) \\
\text { Consumer goods } \\
\text { Business equipment } \\
\text { Defense \& space equipment } \\
\text { Materials }\end{array}$ & $\begin{array}{l}\text { Aug. } \\
\text { Aug. } \\
\text { Aug. } \\
\text { Aug. } \\
\text { Aug. }\end{array}$ & $\begin{array}{l}9-14-79 \\
9-14-79 \\
9-14-79 \\
9-14-79 \\
9-14-79\end{array}$ & $\begin{array}{r}150.9 \\
147.7 \\
170.3 \\
92.9 \\
155.3\end{array}$ & $\begin{array}{r}-13.4 \\
-25.4 \\
-9.1 \\
6.5 \\
-12.2\end{array}$ & $\begin{array}{r}-3.9 \\
-11.3 \\
-2.6 \\
1.7 \\
-1.0\end{array}$ & $\begin{array}{r}2.0 \\
-1.9 \\
4.2 \\
5.7 \\
3.4\end{array}$ \\
\hline $\begin{array}{l}\text { Consumer prices all 1tems }(1967=100) \\
\text { All 1tems, excluding food \& energy } \\
\text { Food }\end{array}$ & $\begin{array}{l}\text { Aug. } \\
\text { Aug. } \\
\text { Aug. }\end{array}$ & $\begin{array}{l}9-25-79 \\
9-25-79 \\
9-25-79\end{array}$ & $\begin{array}{l}220.7 \\
209.4 \\
235.0\end{array}$ & $\begin{array}{r}12.6 \\
12.2 \\
.0\end{array}$ & $\begin{array}{r}12.1 \\
10.4 \\
1.2\end{array}$ & $\begin{array}{r}11.7 \\
9.9 \\
9.5\end{array}$ \\
\hline $\begin{array}{l}\text { Producer prices: }(1967=100) \\
\text { Finished goods } \\
\text { Intermediate materials, nonfood } \\
\text { Crude foodstuffs \& feedstuffs }\end{array}$ & $\begin{array}{l}\text { Sept. } \\
\text { Sept. } \\
\text { Sept. }\end{array}$ & $\begin{array}{l}10-4-79 \\
10-4-79 \\
10-4-79\end{array}$ & $\begin{array}{l}221.0 \\
251.5 \\
249.9\end{array}$ & $\begin{array}{l}17.1 \\
18.4 \\
17.5\end{array}$ & $\begin{array}{l}14.8 \\
18.5 \\
13.2\end{array}$ & $\begin{array}{l}11.8 \\
14.8 \\
13.8\end{array}$ \\
\hline Personal Income ( $\$$ b1l.) $2 /$ & Aug. & $9-18-79$ & 1938.1 & 5.2 & 9.8 & 11.3 \\
\hline & & & & & $\underline{t}$ at annu & 11 rates \\
\hline $\begin{array}{l}\text { Mfrs. new orders dur. goods }(\$ \text { bil. }) \\
\text { Capital goods industries } \\
\text { Nondefense } \\
\text { Defense }\end{array}$ & $\begin{array}{l}\text { Aug. } \\
\text { Aug. } \\
\text { Aug. } \\
\text { Aug. }\end{array}$ & $\begin{array}{l}10-3-79 \\
10-3-79 \\
10-3-79 \\
10-3-79\end{array}$ & $\begin{array}{r}74.6 \\
24.5 \\
21.5 \\
3.0\end{array}$ & $\begin{array}{r}2.9 \\
8.6 \\
6.1 \\
30.8\end{array}$ & $\begin{array}{r}-3.2 \\
-.4 \\
2.4 \\
-16.7\end{array}$ & $\begin{array}{r}5.6 \\
13.5 \\
16.9 \\
-6.3\end{array}$ \\
\hline $\begin{array}{l}\text { Inventories to sales ratio: } 1 / \\
\text { Manufacturing and trade, total } \\
\text { Manufacturing } \\
\text { Trade }\end{array}$ & $\begin{array}{l}\text { July } \\
\text { Aug. } \\
\text { July }\end{array}$ & $\begin{array}{l}10-3-79 \\
10-3-79 \\
10-3-79\end{array}$ & $\begin{array}{l}1.44 \\
1.54 \\
1.34\end{array}$ & $\begin{array}{l}1.43 \\
1.54 \\
1.33\end{array}$ & $\begin{array}{l}1.44 \\
1.48 \\
1.33\end{array}$ & $\begin{array}{l}1.44 \\
1.51 \\
1.33\end{array}$ \\
\hline $\begin{array}{l}\text { Rat1o: Mfrs.' durable goods inven- } \\
\text { tories to unfilled orders } \underline{1} \text { / }\end{array}$ & Aug. & $10-3-79$ & .563 & .557 & .546 & .600 \\
\hline $\begin{array}{l}\text { Retail sales, total ( } \$ \text { bil.) } \\
\text { GAF } \underline{3} /\end{array}$ & $\begin{array}{l}\text { Aug. } \\
\text { Aug. }\end{array}$ & $\begin{array}{l}9-10-79 \\
9-10-79\end{array}$ & $\begin{array}{l}72.8 \\
16.1\end{array}$ & .7 & $\begin{array}{l}1.2 \\
2.7\end{array}$ & $\begin{array}{l}8.1 \\
9.0\end{array}$ \\
\hline $\begin{array}{l}\text { Auto sales, total (mil. units.) } \underline{2} \\
\text { Domestic models } \\
\text { Forelgn models }\end{array}$ & $\begin{array}{l}\text { Sept. } \\
\text { Sept. } \\
\text { Sept. }\end{array}$ & $\begin{array}{l}10-3-79 \\
10-3-79 \\
10-3-79\end{array}$ & $\begin{array}{r}10.7 \\
8.5 \\
2.2\end{array}$ & $\begin{array}{l}-2.4 \\
-2.6 \\
-1.7\end{array}$ & $\begin{array}{l}12.3 \\
19.2 \\
-8.3\end{array}$ & $\begin{array}{r}.9 \\
-1.9 \\
13.7\end{array}$ \\
\hline $\begin{array}{l}\text { Housing starts, private (thous.) } 2 / \\
\text { Leading Indicators (1967-100) }\end{array}$ & $\begin{array}{l}\text { Aug. } \\
\text { Aug. }\end{array}$ & $\begin{array}{l}9-19-79 \\
9-28-79\end{array}$ & $\begin{array}{l}1,783 \\
139.1\end{array}$ & $\begin{array}{r}-.4 \\
.0\end{array}$ & $\begin{array}{r}-2.8 \\
-.5\end{array}$ & $\begin{array}{r}-11.0 \\
-2.0\end{array}$ \\
\hline
\end{tabular}


forces and lend support to the dollar in foreign exchange markets. Such a package might include actions on reserve requirements and the discount rate; in addition, the staff had been asked to analyze the implications of a possible shift in Federal Open Market Committee procedures, whereby the Desk, in its day-to-day operations, would operate more directly on a bank reserves, rather than a Federal funds rate, target. (BOG, Minutes, 10/4/1979, pp. 1-2)

The Minutes indicate that "Board members agreed on the seriousness of the situation and on the need for action" but postponed taking decisions on reserve requirements and the discount rate until Saturday, when the special FOMC meeting was to be held (BOG, Minutes, 10/4/1979, pp. 2-4).

That same day, the background memorandum on the proposed new operating procedures that Stephen Axilrod and Peter Sternlight were preparing at Chairman Volcker's request was finalized and sent electronically to the FOMC. The Axilrod and Sternlight memorandum envisioned that the FOMC would specify desired short-run growth rates for M1 and other monetary aggregates. The staff would then construct the associated paths for total reserves and the monetary base. The memorandum also suggested another point at which an FOMC decision would be a crucial aspect of the newly structured operations.

A method for setting the level of nonborrowed reserves would be to take the average level of borrowing in recent weeks and subtract them from total reserves. Or the Committee could take a different level of borrowing-either higher or lower-depending in part on whether it wishes to tilt money market conditions toward tightness or ease in the period ahead. Whether money market interest rates would tend to rise, or rise more than they otherwise would, then depends on whether the demand for the total monetary base or total reserves were strong relative to the FOMC's path. If strong, the funds rate and the level of member banks borrowing would tend to rise as the Desk adhered to the initial path level \{of\} nonborrowed reserves. Conversely, if demands were weak, the funds rate, and the level of member bank borrowing, would tend to decline. (Axilrod and Sternlight, 1979, p. 7)

The FOMC held a last-minute informationsharing conference call on October 5.

Chairman Volcker...You will have very shortly, if you don't already, a memorandum that Steve Axilrod and Peter Sternlight prepared describing a possible approach that involves leaning more heavily on the aggregates in the period immediately ahead. And the complement of that is leaning less heavily on the federal funds rate in terms of immediate policy objectives. We have had some considerable discussion of that over the past couple of weeks here and that memorandum attempts to distill some of the thinking. I want to discuss tomorrow whether to adopt that approach, not as a permanent [decision] at this stage, but as an approach for between now and the end of the year, roughly, in any event. (FOMC, Transcript, 10/5/1979, p. 1)

He also referred to the unstable conditions in commodities markets.

Chairman Volcker. The discussions abroad were very difficult in a number of respects. The feeling of confidence is not high, I should say, in a number of directions and that increases the difficulty of restoring a sense of stability. One of the alarming things earlier, to me at least, was the sensitivity and responsiveness of some of the commodity markets outside of gold and silver to what was going on. There were some very sharp increases in prices of copper and other metals at the end of last week and at the beginning of this week, a development that has since subsided somewhat with the improvement in the gold market and the exchange market. But, quite clearly, we are in a very sensitive period. (FOMC, Transcript, 10/5/1979, p. 4)

The momentous special meeting convened at 10:10 am on Saturday. Chairman Volcker framed the issues.

Chairman Volcker...We wouldn't be here today if we didn't have a problem with the state of the markets, whether international or domestic. They were pretty feverish last week-or beginning in the previous week, really. Beginning 
about 2 weeks ago and carrying over into the early part of what is still this week, the foreign exchange market was in a situation that was clearly not amenable for very long to such techniques as intervention. The markets have turned around some in the past few days, as you know. I think that is almost entirely explicable by the fact that at about the time I returned from Belgrade Treasury officials and others were making some statements that left hanging the possibility of some kind of a package, so the foreign exchange dealers have retreated to the sidelines...

In terms of the economy...my own concerns about the risks of the economy falling off the table, though they have not evaporated, have diminished a bit... On the price front, expectations have certainly gotten worse rather than better...I certainly conclude from all this that we can't walk away today without a program that is strong in fact and perceived as strong in terms of dealing with the situation...\{W\}e are not dealing with a stable psychological or stable expectational situation by any means. And on the inflation front we're probably losing ground. In an expectational sense, I think we certainly are, and that is being reflected in extremely volatile financial markets...\{Regarding\} the commodities issue\{, b\}eginning a little more than a week ago, late in the previous week when the gold market was gyrating, there was some very clear evidence that this psychology was getting into the metals markets in particular in a very forceful way and maybe in the grains markets very temporarily...The psychology in the foreign markets is the same as the psychology at home; it is reflected in the metals markets. It is the inflationary psychology or whatever. (FOMC, Transcript, 10/6/1979, pp. $4-6,12,15)$

Chairman Volcker argued, however, that overall inflation data were not alarming as yet.

Chairman Volcker...Even though the price news is bad, it does not in my judgment as yet reflect a spreading of the whole inflationary force into areas outside of energy. We had a fluctuation in food [prices] last month, but that [component of the price index] goes up and down. If we look at the wage trend, so far as we know-with the exception of the General Motors settlement-we haven't had a real breakout yet. But we're dealing with a situation where that's an imminent danger on the one side as is the possibility of a recession on the other side. (FOMC, Transcript, 10/6/1979, p. 5)

Chairman Volcker then laid out the specific options.

Chairman Volcker...Now, when it comes to our action here, I think there are broadly two possibilities. One is taking measures of what might be thought of as the traditional type. That would include a discount rate move on the one side and so far as this Committee is concerned a significant increase in the federal funds rateputting those moves together. The Board will be considering some reserve requirement changes later today. Let's assume that the package would include that...

The other possibility is a change in the emphasis of our operations as outlined in the memorandum that was distributed, which I hope you've all had a chance to read. That involves managing Desk operations from week to week essentially, with a greater effort to bring about a reserve path that will in turn achieve a money supply target-which we have to discuss-recognizing that that would require a wider range for the federal funds rate and would involve a more active management of the discount rate. And of course the question of reserve requirements and the discount rate change at this point are relevant in that context too. (FOMC, Transcript, 10/6/1979, pp. 7-8)

In presenting the pros and cons of each option, Chairman Volcker first mentioned that changing operating procedures had occurred to him some time ago.

Chairman Volcker...I must say that the thought of changing our method of operations germinated-in my mind at least-before the market psychology or nervousness reached the extreme stage it reached over the past week or so. My feeling was that putting even more emphasis on meeting the money supply targets and changing operating techniques [in order to do so] and thereby changing psychology a bit, we might actually get more bang for the buck...I overstate 
it, but the traditional method of making small moves has in some sense, though not completely, run out of psychological gas. (FOMC, Transcript, 10/6/1979, p. 8)

He made it clear that the choice of the initial borrowing assumption, in principle, should be based on the same predicted level of the federal funds rate (converted to a spread over the discount rate) that was associated with the projection of near-term M1 growth matching the FOMC's target path for that aggregate.

Chairman Volcker...Suppose we happen to put a lot of weight on the current projection of the money supply and pick figures that would closely coincide with that. We would then provide, making some assumption on the level of borrowing that seemed to be consistent with the level of interest rates that presumably laid behind the projection of the money supply in the first place-we can't avoid interest rate assumptions the way these things are donenonborrowed reserves along that path. If the money supply actually grew faster, borrowings would go up and presumably interest rates would go up; if the reverse happened, borrowings would go down and interest rates would go down. (FOMC, Transcript, 10/6/1979, p. 25)

(Instead, the procedure for giving the FOMC alternative initial borrowing assumptions that was put forth in the aforementioned AxilrodSternlight memorandum was in fact followed in practice for a little longer than a year.)

Chairman Volcker said that he could live with either option but again stated that in his mind a decision to adopt the second one would be only temporary.

Chairman Volcker...I am prepared, within the broad parameters, to go with whichever way the consensus wants to go so long as the program is strong, and if we adopt the new approach so long as we are not locked into it indefinitely. If we adopt the new approach, I'd consider it something that we adopted that seems particularly suitable to the situation at this time. (FOMC, Transcript, 10/6/1979, p. 10)

The Committee discussed whether a change in procedures would lock it in for a considerable period.
Mr. Eastburn...There's a credibility problem if we launch this and stop and go with it. So I really think we are committed to this if we go [forward].

Chairman Volcker. Well, I don't want to accept that. I don't think we can make that decision now. If we [change our operating technique], I do accept the fact that to some degree we have prejudiced the discussion we will have at the end of the year. We will have to have a reason then to move back to the traditional method. But I don't think we can really make that decision now, nor should we. Nor do I think this commits us that fully, though it prejudices to some degree what we would do next year. (FOMC, Transcript, 10/6/1979, p. 15)

Chairman Volcker...There's an immediate advantage in the publicity \{regarding the change in technique\}; there is a disadvantage not very far down the road if people read this as a commitment and in fact we are not going to be able to live up to that commitment. (FOMC, Transcript, 10/6/1979, p. 27)

He later noted he preferred that such a decision be reconsidered around year-end, which arose from his sense that money demand historically had been plagued by institutional innovation and hence instability.

Chairman Volcker...That's the [reason] I'm not willing to make a judgment at this point as to the long-run desirability of this technique through thick and thin and in all possible circumstances.

So, I would remind you that because of the particular circumstances I am thinking of using this technique for the [coming] 3- or 4-month period. This is a time when it may be particularly important to our credibility and to the economy and to psychology and everything else that we provide ourselves with greater assurance that we will get a handle on the money supply. (FOMC, Transcript, 10/6/1979, p. 28)

In the course of Committee deliberation, President Roos of the Federal Reserve Bank of St. Louis presented only a limited statement.

Mr. Roos. Well, Mr. Chairman, I assume that my credibility with you and my colleagues would 


\section{Lindsey, Orphanides, Rasche}

be severely jeopardized if I came out flatly in opposition to this proposal! [Laughter] I also was told by my father to keep my mouth shut when things are going well. So all I'll say is briefly: God bless you for doing this! [Laughter] (FOMC, Transcript, 10/6/1979, p. 24)

After Committee discussion, a straw poll was conducted of all the governors and presidents. Staying with the traditional method was preferred by five of those present (FOMC Transcript, 10/6/1979, p. 50). However, a majority preferred switching to the new technique, and the final official vote was unanimous.

Immediately following the FOMC meeting, at 1:30 pm, the Board met to consider discount rate and reserve requirement actions. The Board unanimously approved a 1-percentage-point increase in the basic discount rate, a comparable rise in subsidiary rates, and an 8 percent marginal reserve requirement on managed liabilities (BOG, Minutes, 10/6/1979, pp. 1-7).

The Board authorized a press release describing all of these actions. The press release stated prominently that the Committee's and the Board's respective votes on the actions taken were unanimous. In characterizing the essence of the new technique, the release noted its temporary rationale.

Actions taken are:...3. A change in the method used to conduct monetary policy to support the objective of containing growth in the monetary aggregates over the remainder of this year within the ranges previously adopted by the Federal Reserve. These ranges are consistent with moderate growth in the aggregates over the months ahead. This action involves placing greater emphasis in day-to-day operations on the supply of bank reserves and less emphasis on confining short-term fluctuations in the federal funds rate. (BOG, 1979d, p. 1)

Then a press conference was scheduled for 6:00 p.m.

Mr. Volcker. I think in general you know the background of these actions; the inflation rate has been moving at an excessive rate and the fact that inflation and the anticipations of inflation have been unsettling to markets both at home and abroad. That unsettlement in itself and its reflection in some commodity markets is, I think, contrary to the basic objective of an orderly development of economic activity.

(BOG, 1979e, p. 1)

He indicated that the purpose of the new procedures was to hit the money growth ranges for the current year, but any sense that the FOMC had adopted the techniques only provisionally was lost on everyone:

Mr. Volcker. I would emphasize that the broad thrust is to bring monetary expansion and credit expansion within the ranges that were established by the Federal Reserve a year ago. (BOG, 1979e, p. 2)

Finally, Chairman Volcker was asked about the real-side impact of the new initiatives.

Question. But in immediate terms does it have an effect that will tend to slow down economic growth that is already too wishy-washy in this country?

Mr. Volcker. Well, you get varying opinions about that. I don't think it will have important effects in that connection. I would be optimistic in the results of these actions. But we're in an area dealing with economic events that are not fully predictable. I think the main thing to say about the economy right now is that it is somewhat stronger than anticipated. The outlook continues to be, in a general way, that some inventory adjustment may be in prospect. I think the best indications that I have now in an uncertain world is that it can be accomplished reasonably smoothly. (BOG, 1979e, p. 8)

At a White House press conference the same day, Jody Powell read the following official Presidential statement:

The administration believes that the actions decided upon today by the Federal Reserve Board will help reduce inflationary expectations, contribute to a stronger U.S. dollar abroad, and curb unhealthy speculations in commodity markets.

Recent high rates of inflation, led by surging oil prices, other economic data, as well as developments in commodity and foreign 
exchange markets, have reinforced the administration's conviction that fighting inflation remains the Nation's number one economic priority.

The administration will continue to emphasize a policy of budgetary restraint. Enactment of effective national energy legislation to reduce dependence on foreign oil is vital to long-term success in this effort.

The administration believes that success in reducing inflationary pressures will lead in due course both to lower rates of price increases and to lower interest rates. (Carter, 1980, p. 1835)

After the initial events on October 6, Chairman Volcker made several additional public appearances to explain the various actions. In a speech to the American Bankers Association (ABA) on the morning of Tuesday, October 9, he provided an overview.

Those measures were specifically designed to provide added assurance that the money supply and bank credit expansion would be kept under firm control. There will be one seemingly technical, but potentially significant, change in procedure in conducting open market operations. More emphasis will be placed on limiting the provision of reserves to the banking system-which ultimately limits the supply of deposits and money-to keep monetary growth within our established targets for this year. We have raised the discount rate-and will manage it more flexibly—so that restraint on bank reserves will not be offset by excessive borrowing from the Federal Reserve Banks. We have placed a special marginal reserve requirement of 8 percent on increases in "managed liabilities" of larger banks (including U.S. agencies and branches of foreign banks) because that source of funds has financed much of the recent buildup in credit expansion. That requirement, admittedly cumbersome by its nature, will be maintained so long as credit expansion is excessive...

As the rate of increase in energy prices subsides-as it should in coming months-the inflation rate as a whole should also decline appreciably. Looked at another way, the immediate challenge is to avoid imbedding the cur- rent rate of inflation in expectations and wage and pricing decisions, before the current bulge in prices subsides. That is not an unrealistic objective, but it is one that will require discipline over the months ahead. (Volcker, 1979a, pp. 3, 8)

In that speech, he added,

Attempts to pin all blame for inflation on factors outside our control would only doom our efforts to futility. (Volcker, 1979a, p. 8)

That Tuesday morning as well, the WSJ ran a story that included this paragraph:

Among those who are skeptical that the Fed will really stick to an aggregate target is Alan Greenspan, president of Townsend-Greenspan \& Co., a New York economics consultant. Mr. Greenspan, who served as chief economic advisor to Presidents Nixon and Ford, questions whether, if unemployment begins to climb significantly, monetary authorities will have the fortitude to "stick to the new policy."7 (WSJ, 1979g, pp. 1, 6)

The WSJ published a story the following day, Wednesday, October 10, that included more information: Additional meetings had been held on October 9.

Officials of the Federal Reserve Bank of New York held separate meetings yesterday with reporters and securities dealers in an effort to clear up some of the confusion surrounding details of the Federal Reserve's anti-inflation techniques announced Saturday.

Peter D. Sternlight, Senior Vice President of the New York Fed, said he doesn't know all of the answers yet. "We're in the midst of a

\footnotetext{
7 While he expressed some doubt as to whether the Federal Reserve would follow through with the program, Greenspan was certainly supportive. Indeed, in congressional testimony on November 5, 1979, he strongly defended the Federal Reserve: "I thus conclude that for the United States there is little leeway for policy maneuvering in the monetary area and that the focus, as it should have been all along, must be on defusing underlying inflationary pressures... 1980 is likely to be a recession year and high interest rates are unquestionably going to exaggerate and prolong any recession. It would be a mistake, however, to attribute the interest rate increases to the Federal Reserve. Its options are limited. The problems reflect earlier inflationary policies. Unless and until we can reverse them, a restoration of balance in our economy will remain illusive" (U.S. Congress Joint Economic Committee, 1980, pp. 7-8).
} 
learning process ourselves," he said. "We have some objectives but don't have procedures at this stage..."

Mr. Sternlight also said the Fed doesn't plan to be "rigid or mechanistic" in pursuit of bankreserve targets. "This may cause some die-hard monetarists to subdue their elation at our change in approach and recall their congratulatory messages," he said...

When a reporter asked what rates the public should watch for clues to Fed thinking, Mr. Sternlight replied: "I'm not sure I have a ready substitute to proffer at this point." He emphasized that "we're still very much experimental" at this stage.

Mr. Sternlight said one key figure the Fed would pay attention to is "nonborrowed reserves.” But he emphasized that the Fed won't rely exclusively on this and plans to remain flexible in its approach. (WSJ, 1979h, p. 3)

Besides not reassuring the dealers (Melton, 1985, p. 49), this briefing content was received with a certain displeasure at the Board in Washington, as it seemed to undermine both the Federal Reserve's commitment to the new approach and the care with which the new procedures had been thought-through in advance (David Lindsey's recollection).

On Wednesday, the day that the story above was published, "a Fed official," perhaps Chairman Volcker, spoke to the WSJ, which published the following story:

As markets gyrated in the uncertainty following the Federal Reserve Board's weekend policy switch, a Fed official warned that the central bank will continue to be unpredictable.

"Anybody looking for a rule of thumb is going to be frustrated," the official said in an interview that sketched a picture of a more flexible-and probably tougher-Fed.

"There are still going to have to be policy judgments made," the official said, indicating the central bank "isn't going to trap itself by following any rule." He said the Fed will try to steer between the "two extremes" of its old practice of inching the federal funds rate up and down and "letting the funds rate go anyplace forever...”
The Reserve Board official observed that the markets were "scrambling" for clues to get a "more definite" picture of the Reserve Board's future behavior. But he added "There isn't any sense in scrambling. It doesn't exist. We changed the procedure. What the limits are going to be aren't clear yet." (Conderacci, 1979, p. 3)

The WSJ reported that reactions among monetarists varied widely. Some were jubilant.

Overcast skies here yesterday did little to dampen the spirits of Laurence K. Roos...

Although the bank was closed because of Columbus Day, Mr. Roos was in his office in downtown St. Louis, and he was beaming. "Except for the unfortunate coincidence of the holiday, champagne and beer would be flowing in the aisles here," he says with a broad smile. (Garino, 1979, p. 6)

But feelings of euphoria did not extend to monetarists in academia.

As more details of the Fed's program emerge from talks with Fed officials, some financial experts believe the Fed will continue to encounter difficulties trying to rein in the growth of the money supply...

Nevertheless, Fed officials say they believe they can enforce and execute their program announced Saturday evening. They acknowledge, though, that some aspects are so new that they don't have all the details worked out yet...

Separately, some economists were disheartened by remarks made by Peter D. Sternlight... that "we don't plan to be rigid or mechanistic" in pursuit of bank reserve targets and will continue looking at many other factors.

That worries Allan H. Meltzer, an economics professor at Carnegie-Mellon University. He says that the Fed may try to fine-tune more items than it has the power to do and that the money supply may get out of control. He urges the Fed to focus on the "monetary base"..."I didn't send them a congratulatory telegram," he says. "I'm going to hold my breath and hope they don't screw it up." (Herman, 1979, p. 6)

Another story continued in the same vein.

Together with Allan H. Meltzer...Professor [Karl] Brunner six years ago set up the Shadow 
Open Market Committee, a group...that meets twice a year to appraise the work of the Fed's key policymaking group. The verdict more often than not has been unfavorable.

Prof. Brunner up to now sees no reason to change...

Politics aside, monetarists question whether the Federal Reserve has chosen the best operating technique...

According to the Federal Reserve plan, estimates for nonborrowed reserves will largely determine what the Fed does as it tries to hit its desired monetary growth rate. Prof. Brunner wonders why the system does not simplify its task by focusing solely on the monetary base. Statistical studies, he says, have shown that the relationship between the base and the gross national product has been smooth and predictable since World War II. Prof. Brunner is quick to admit that Mr. Volcker sounds much better than some of his immediate predecessors. The new chairman has been much more willing to concede that the Fed deserves much of the blame for the existing inflation. $\mathrm{He}$ stresses that the important need now is not just to articulate a new policy but to stick with it...

But monetarists have been burned so often that for now they will withhold their cheers. Securities markets seem similarly skeptical that the Fed finally is determined to stop inflation... (Clark, 1979, p. 22)

To further explain the FOMC's actions, Chairman Volcker appeared on the MacNeilLehrer News Hour on October 10. His first comment reacted to the earlier view of experts that, as a newly appointed Federal Reserve Chairman, he wouldn't make any radical changes.

Paul Volcker. Well, I don't know that these are radical changes in Federal Reserve policy in a very fundamental sense. We want to deal with this problem of inflation, and I think that intention was perhaps reinforced in the public mind by the actions we took on Saturday; but in a very basic sense the policy has been there and we intend to carry it out. (MacNeil-Lehrer News Hour, 1979, p. 1)

Commenting on the market reaction, he went on to underscore the point that the Federal Reserve was determined to bring down both actual and expected inflation.

Paul Volcker. I think the point may be that we captured their attention....and I think that's constructive in a sense, because there've been a lot of doubts, a lot of anxiety that this inflation was going to get out of control. And it's not going to get out control if we do our job...[A] lot of people were skeptical whether we could deal with it. I hope they're less skeptical now than they were before... (MacNeil-Lehrer News Hour, 1979, p. 2)

He stressed the long-run rather than the short-run effect on real economic activity.

Paul Volcker. And this is the kind of circumstance which leads to concern about recession; and I share that concern. But...[i]f inflation got out of hand, it's quite clear that that would be the greatest threat to the continuing growth of the economy, to the productivity of the economy, to the investment environment, and ultimately to employment...Now, I'm not saying that unemployment will not rise. I am saying the greater threat over a period of time would come from failing to deal with inflation rather than efforts to deal with it. (MacNeil-Lehrer News Hour, 1979, p. 6-7)

In a subsequent appearance on Issues and Answers on October 29, he spoke further.

Mr. Volcker. We are in a very difficult economic situation, but I would not, in terms of a possible recession, which has been discussed for months, trace that to our particular actions. The situation we had was rising inflation, speculation, a weak dollar. (ABC News' Issues and Answers, 1979, p. 2)

On October 17, before the Joint Economic Committee, Chairman Volcker dealt in more detail with the effect on public attitudes of the "serious inflationary environment we are now facing."

An entire generation of young adults has grown up since the mid-1960s knowing only inflation, indeed an inflation that has seemed to accelerate inexorably. In the circumstances, it is hardly surprising that many citizens have 
begun to wonder whether it is realistic to anticipate a return to general price stability, and have begun to change their behavior accordingly. Inflation feeds in part on itself. So part of the job of returning to a more stable and more productive economy must be to break the grip of inflationary expectations.

We have recently seen clear evidence of the pervasive influence of inflationary expectations on the orderly functioning of financial and commodity markets, and on the value of the dollar internationally. Over a longer period of time, the uncertainties and distortions inherent in inflation have a debilitating influence on investment, productivity and growth. In the circumstances, the overwhelming feeling in the nation-that we must come to grips with the problem-reflects the common sense of the American people. At the same time, we have to recognize that, after more than four years of expansion, there are widespread anticipations of inventory adjustments and a downturn in economic activity. The challenge is to deal with this troublesome situation in a manner that promises, over a period of time, to restore a solid base for sustained growth and stability... Above all, the new measures should make abundantly clear our unwillingness to finance a continuing inflationary process. (Volcker, 1979b, pp. 1-2, 4)

Before the National Press Club early in 1980, he underlined these monetary sources of sustained inflation.

Our policy, taken in a longer perspective, rests on a simple premise-one documented by centuries of experience-that the inflationary process is ultimately related to excessive growth in money and credit. I do not mean to suggest that the relationship is so close, or that economic reality is so simple, that we can simply set a monetary dial and relax...But, with all the complications, I do believe that moderate, non-inflationary growth in money and credit, sustained over a period of time, is an absolute prerequisite for dealing with the inflation that has ravaged the dollar, undermined our economic performance and prospects, and disturbed our society itself. (Volcker, 1980a, pp. 3-4)
Chairman Volcker contended on January 15, 1980, that poor forecasts can undermine antiinflationary policy.

[I]t's a dangerous game to change basic policies on the basis of short-term forecasts at any particular point in time. Forecasts of the shortrun outlook are so often fallible that they're almost as apt to be wrong as right.

In the past, in shaping our nation's policies, I think we've had an insidious tendency to anticipate the worst in terms of unemployment in particular; and we always anticipate the worst and act on those anticipations over time. That's a recipe for too much expansionary action and ultimately for inflation. Today our margins for error in that connection are less than they have ever been and I think that we should not make that mistake again. (Volcker, 1980e, p. 42)

Then, before the Joint Economic Committee on February 1, he noted

the almost universal failure of forecasts made at this time last year, and throughout most of the year, to predict accurately the continued expansion of economic activity in 1979. Despite the shocks from very large oil price hikes, fuel shortages, and major strikes, as well as the imposition of restraining macroeconomic policies, the economy proved to be remarkably resilient. Growth in real economic activity did slow in 1979 from the unsustainable 5 percent rate posted in the preceding year, but real GNP still advanced 1 percent over the four quarters of 1979; the much-heralded recession never appeared.

The 1979 experience underscores how limited our ability is to project future developments. It reinforces the wisdom of holding firmly to monetary and other economic policies directed toward the evident continuing problems of the economy —of which inflation ranks first-rather than reacting to possibly transitory and misleading movements in the latest statistics or relying too heavily on uncertain economic and financial forecasts. In retrospect, recharting policy to respond to tentative signs of a faltering economy last year would have proven extremely costly to our anti-inflation effort. (Volcker, 1980b, p. 76) 
In his first Humphrey-Hawkins testimony on February 19, 1980, Chairman Volcker amplified his critique of approaching monetary policy in such a way.

In the past, at critical junctures for economic stabilization policy, we have usually been more preoccupied with the possibility of near-term weakness in economic activity or other objectives than with the implications of our actions for future inflation. To some degree, that has been true even during the long period of expansion since 1975. As a consequence, fiscal and monetary policies alike too often have been prematurely or excessively simulative or insufficiently restrictive. The result has been our now chronic inflationary problem, with a growing conviction on the part of many that this process is likely to continue. Anticipations of higher prices themselves help speed the inflationary process...

The broad objective of policy must be to break that ominous pattern. That is why dealing with inflation has properly been elevated to a position of high national priority. Success will require that policy be consistently and persistently oriented to that end. Vacillation and procrastination, out of fears of recession or otherwise, would run grave risks. Amid the present uncertainties, stimulative policies could well be misdirected in the short run. More importantly, far from assuring more growth over time, by aggravating the inflationary process and psychology, they would threaten more instability and unemployment. (Volcker, 1980d, pp. 2-3)

The reception given to the new operating procedures at the February Humphrey-Hawkins hearings by the House and Senate banking committees was generally, though not universally, welcoming. The House Committee on Banking, Finance, and Urban Affairs was chaired by Representative Henry Reuss, a Democrat from Wisconsin. Despite his support, the tone of the other representatives was mixed. Even so, the congressional committee's monetary-policy report, published in April, approved of "a cautious moderation of monetary growth in 1980 and into the future for some years to come." The report called the new operating procedures "a change we applaud" and even recommended contemporaneous reserve requirements! (U.S. House of Representatives, 1980c, pp. 2-4). William Proxmire, a Democrat from Wisconsin, although an independent maverick, was chairman of the Senate Committee on Banking, Housing, and Urban Affairs. He approved of the "aggressive" policy under Chairman Volcker. He even noted "continuing doubts that the Federal Reserve will continue to pursue a tight monetary policy in a Presidential election year.” The only other senator to address the issue, Jake Garn, a Utah Republican, also took an anti-inflationary position (U.S. Senate, 1980, pp. 1-3).

On a more technical level, an official summary of the operational details of the new procedures, dated January 30, 1980, appeared as an appendix to both testimonies by Chairman Volcker, on February 1 and February 19, as well as to another of his testimonies on February 4, 1980 (Volcker, 1980c). This document identified and described in detail eight separate steps constituting the procedures. It also discussed
how the linkage between reserves and money involved in the procedures is influenced by the existing institutional framework and other factors...The exact relationship depends on the behavior of other factors besides money that absorb or release reserves, and consider- ation must also be given to timing problems in connection with lagged reserve accounting. (U.S. House of Representatives, 1980a, p. 1)
This document was released only after the Committee discussed on January 8, 1980, whether to continue with the new procedures. Chairman Volcker began the discussion; it cannot be said that the Committee's decision turned into a sus- penseful cliffhanger:

Chairman Volcker...I just want to be explicit about whether we want to continue this general type of procedure. Obviously, we're on it and it has worked; on the surface, anyway, it has worked. The results are more or less in line with what was intended. And I think it continues to have some of the advantages that were foreseen originally. While we still worry about 
what the federal funds rate is doing, when it doesn't go according to our preconception, we at least avoid making a concrete decision...

$\{\mathrm{A}\} \mathrm{s}$ a broad thrust, I think the question is whether or not to continue basically what we've been doing.

Mr. Partee. Shifting back from a very successful experiment certainly would be hard to explain.

Chairman Volcker. There's no question.

Mr. Morris. The reaction would be devastating.

Mr. Partee. It surely would.

Mr. Balles. Unthinkable. (FOMC, Transcript, 1/8-9/1980, pp. 13-14)

Despite the technical description, some confusion about the new procedures persisted. Governor Wallich expressed the point a month after the description was first released as follows:

The new procedures of the Federal Reserve have given rise to some understandable misconceptions that suggest that the Federal Reserve has not been fully effective in making itself understood. (Wallich, 1980, p. 9)

\section{WHY?}

Looked at from a deeper perspective than mere historical narrative, the question can be asked as to the reasons for the FOMC's adoption of the new operating procedures-that is, why? Listed roughly in order of decreasing obviousness, the reasons are as follows:

1. restoring more certain public confidence in the Federal Reserve

2. by allowing more certain restraint over longterm inflation,

3. by more clearly abandoning a policy strategy of "gradualism" and

4. by gaining more certain control over intermediate-term money growth,

5 . by clearly switching from the federal funds rate on the money-demand side to nonborrowed reserves on the money-supply side as the short-run operating target,
6. thereby permitting the federal funds rate more certain short-run flexibility to attain the needed level in terms both of monetary and inflationary developments,

7. thereby more clearly distancing the FOMC from the particular day-to-day level of the federal funds rate and

8. thereby clearly moving away from a deliberative smooth adjustment of the funds rate and

9. thereby clearly avoiding any reliance on uncertain FOMC estimates of potential output or the Non-Accelerating Inflation Rate of Unemployment (NAIRU) and

10. thereby clearly avoiding any reliance on uncertain FOMC forecasts of output, employment, and inflation and

11. thereby clearly assuming full central bank responsibility for the attainment of longterm price stability, but also

12. thereby more clearly avoiding difficult questions of overt responsibility for intermediate-term real-side developments.

\section{Point One}

The historical narrative in the last section helped to demonstrate that the media commentary and commodity market reaction to the revelation on September 18 of the Board's four-to-three discount-rate vote-without the disclosure of the FOMC's tightening and the accompanying three dissents for even tighter policy-worked together to pound a fatal stake into the credibility of the FOMC as the country's bulwark against inflation. Had the public and the markets received the full picture, then the reaction would very likely have been more subdued. Restoring the public's trust in the System became a paramount end for any actions that the FOMC would contemplate.

\section{Point Two}

According to the narrative history in the previous section, by October 6, 1979, the FOMC evidently had come to view rampant inflation and inflationary expectations as the nation's most serious problem. Judged by actual events, the 
time had come for dramatic action by the Federal Reserve to counter the inflationary threat to the nation's economy. This action would need to be sustained long enough to reduce inflation substantially as well as strengthen public attitudes about the central bank's resolve to do so, because intense inflationary forces and unhinged inflationary expectations were seen to be detrimental to real-side activity. In the strength of its view, upon which it was willing to act decisively, the FOMC was far ahead of its time. Indeed, as the 1970 s began, quite the opposite opinion prevailed-to wit, that some inflation was needed to "grease the wheels" of the market system. Only after the long economic expansions of the last seven years of the 1980s and the last eight years of the 1990s did the damaging effects of inflation rates and expected rates of inflation above low single digits on saving, investment, and productivity become demonstrable.

\section{Point Three}

A strategy of "gradualism" had characterized the FOMC's monetary policy during the 1970s, but the inadequacy of such a strategy had become all too evident as 1979 progressed. By the time of its 1979 Annual Report on August 3, the International Monetary Fund (IMF) put it this way:

In the Fund's 1976 Annual Report, the importance of bringing down inflation and greatly reducing inflationary expectations was stressed. A "gradual" approach was recommendedbut one that "would need to be adhered to firmly..."

Now, three years later, it is clear that the suggested strategy of policy has not led to satisfactory results; for the industrial countries, average rates of inflation and unemployment have not been reduced. The reasons for this unsatisfactory outturn are manifold and complex, but perhaps the basic one has been the pursuit of policies that have failed to make a dent in inflationary expectations. It is evident that governments have felt severe economic and political constraints in launching an effective anti-inflation program, since in the short run this would be bound to have adverse employment effects whose timing and magni- tude would depend primarily on the ability to reduce inflationary expectations and hence would be difficult to predict. Also noteworthy is that economic forecasting and policymaking have been subject to a substantial degree of error in the unaccustomed situation of "stagflation"-an error often compounded, however understandably, by official optimism toward the future or misleading assessments of past developments...

The upshot has been that "gradualism" as an approach to the reduction of inflation and inflationary expectations has been too "gradual"-in many countries, to the point of no reduction at all. This seems clearly evident from the fact that the overall rate of monetary expansion in the industrial countries has not come down, but has remained about 10 percent in every year since 1975... (IMF, 1979, p. 7)

The historical narrative in the previous section suggests that on October 6, the FOMC acted on the same perception. The Committee clearly had become frustrated with the upward march of inflation despite its previous gradualist policy put in place to resist the trend.

\section{Point Four}

As will be discussed more fully below in Point Eleven, Federal Reserve officials had long accorded a significant role in the inflation process to excessive monetary stimulus, along with the important effects imparted by "exogenous factors" that also affected measured inflation. As will be seen in that discussion, however, Chairman Burns had questioned the practical ability of monetary policy to resist the various pressures acting against sufficient monetary restraint to maintain price stability. In opposition to that view, the position of the monetarists had the intellectual attraction of purity—that, on a sustained basis, "inflation was always and everywhere a monetary phenomenon." This argument had a universal acidity that dissolved all other influences on long-term inflation, except for money growth. And the appreciable rise of actual inflation in association with oftenabove-target money growth brought ever-widening support for the monetarist argument that the culprit was none other than the Federal Reserve 
itself. Accordingly, it was ever-more generally perceived that controlling money growth was a prerequisite for controlling inflation.

That money growth had been excessively rapid entering the fall of 1979 could not really be questioned. In the third quarter of the year, the levels of M1 and M2 were 1/1/2 percentage points below the upper bounds of their respective 3 to 6 percent and 5 to 8 percent ranges for the year only because of their respective low -2.1 percent and 1.8 percent rates of change recorded in the first quarter. With M1 and M2 growing at respective rates of 7.6 percent and 9.5 percent in the second quarter and of 8.6 percent and 11.9 percent in the third quarter, the Axilrod-Sternlight memorandum informed the FOMC that

rates of growth have been accelerating and have been above the longer-run ranges, well above most recently...

For the monetary aggregates as a group to be within their ranges by the time the year is over, a considerable slowing from their recent pace is required. (Axilrod and Sternlight, 1979, p. 2)

Taking a longer perspective, the two upper panels of Figure 5 show that, over each of the last four years of the decade of the 1970s, either M1 or M2 growth exceeded the upper bound of its announced annual range. ${ }^{8}$ This experience, of course, had added empirical support for the contention that a causal link connected money growth and inflation. A decade after the procedural change, Stephen Axilrod summarized the approach as follows:

The obvious problem-it was an easy period in that sense-was to control inflation. One way to do it was to impose an M1 rule on yourself, pay little attention to GNP forecasts, and just let the economy adjust...[The FOMC] used M1 successfully as that sort of bludgeon to receive a rapid reduction in inflation... (Axilrod, 1990, pp. 578-79)

Monetarists buttressed their case by contending that monetary targeting on a consistent basis over time-that is, without "base drift"-would

8 This figure is reproduced from Lindsey (1986, p. 177, Exhibit 5-1). take advantage of the longer-run predictability of the velocity of money. Karl Brunner had underscored concern about base drift under the old operating procedures.

It [the Shadow Open Market Committee] also warned that the Federal Reserve's internal procedures were ill suited to execute an effective monetary control. The traditional mode of implementing policy would remain, in the Shadow Committee's view, an uncertain and unreliable instrument for the purposes defined by House Concurrent Resolution 133. The Committee emphasized, moreover, the potential drift built into monetary growth as a result of the peculiar targeting techniques evolved by the Federal Reserve Authorities. (Brunner, 1977, p. 2)

Effective monetary control would ensure, monetarists said, that prices would stay stable on average over time and therefore that inflation expectations at more distant horizons would be anchored at a low level. They contended that several economic advantages would flow from such a situation. They also argued that high and volatile inflation and inflation expectations made reliance on an interest rate as the main operating target for monetary policy even more problematic than it already was otherwise. After all, the significance for spending of a particular nominal interest rate was degraded as uncertainty rose about the true level of the real interest rate and as speculative investment gained in importance.

\section{Point Five}

A separate argument of monetarism was about how to control money growth, asserting that the monetary base or total reserves should be used as the operating target. ${ }^{9}$ The Shadow Open Market Committee (SOMC) expressed the point this way in early February 1980:

The SOMC favors an immediate return to the $6 \%$ growth rate for base money that was achieved in the first and second quarters of

\footnotetext{
${ }^{9}$ See, for example, Johannes and Rasche (1979, 1980, 1981). Table 1 in the 1981 paper translates the "New Federal Reserve Technical Procedures for Controlling Money" into the money multiplier framework used by monetarists.
} 
Figure 5

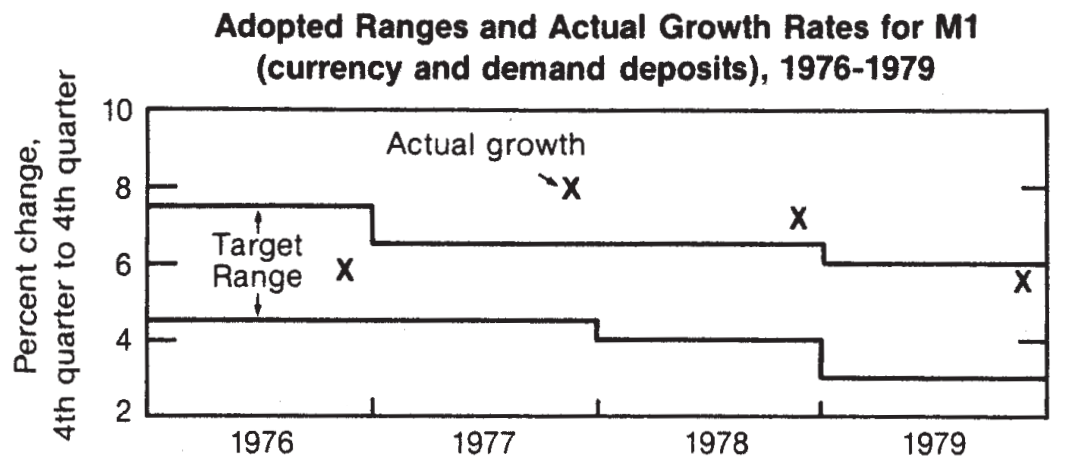

Adopted Ranges and Actual Growth Rates for M2 (M1 plus savings and small
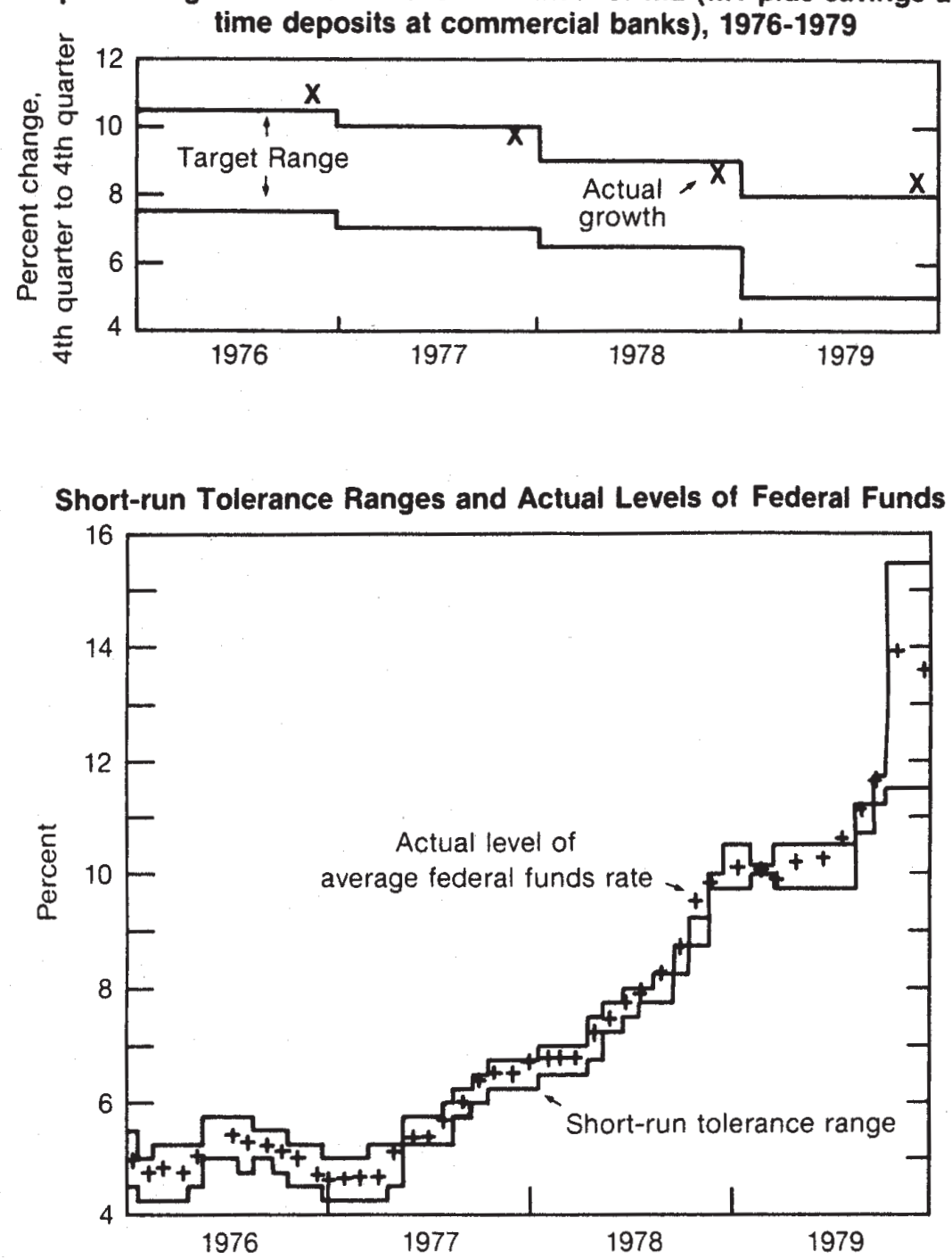
1978. A $6 \%$ average rate of growth of the base in each quarter of 1980 will continue the policy we advocated at our September 1979 meeting. (SOMC, 1980, p. 6-7)

This monetarist argument was rejected by FOMC staff, which drew on a different strand of the literature to recommend nonborrowed reserves as the primary alternative operating target to the federal funds rate. But this strand of the literature did not contend that as a technical matter nonborrowed reserves were superior to the federal funds rate in an empirical horse race in which each approach was used optimally in setting an operating target based on the expected outcome for the money stock; rather, in such a case the two were virtually dead even in controlling money (Sivesind and Hurley, 1980, pp. 199-203; Axilrod and Lindsey, 1981, pp. 246-52).

Instead, what tipped the scales in favor of nonborrowed reserves was the practical observation that a monetary authority deliberately setting the funds rate would be unlikely to select the level that it expected to induce the targeted money stock because the implied volatility of the funds rate would be more than the authority could stomach. Because of what Governor Wallich called "inertia in the adjustment of the funds rate to needed levels under the old procedure," a nonborrowed reserves operating target was thought likely to work out better in practice in controlling money (Wallich, 1980 , p. 5). Even if the authority chose an initial level that would not give rise to the appropriate funds rate for the targeted money growth, further automatic movement of the funds rate within the control period but outside the authority's discretion was believed likely to deliver monetary growth closer to its target than in the case of a funds rate operating target where the initial level was simply maintained. Over time, closer monetary management would imply that inflation would be brought under more certain restraint as well.

\section{Point Six}

The Committee recognized that the switch to a reserves-based approach to monetary control would be more likely to allow the federal funds rate in the short run to move as necessary to what- ever level would prove consistent with more restrained money growth and lower inflation. But given that the appropriate level, as well as the induced automatic movement, could not be known in advance by the monetary authority, for the federal funds rate to have the scope to be significantly more variable, the Committee would have to establish a substantially wider permissible band of funds rate movement. This band, which was published in the directive, is portrayed in the lower panel of Figure 5 introduced in Point Four. On October 6, the Committee widened this band from $1 / 2$ percentage point to 4 percentage points. The small crosses in that panel, which depict the average federal funds rate between FOMC meetings, also suggest that federal funds in fact began trading over a much wider range.

Figure 6 offers an alternative perspective: A standard forward-looking Taylor rule has a tendency to predict a funds rate from early 1976 through mid-1979 that not only exhibits fairly subdued movements but also comes reasonably close to the actual funds rate set by the FOMC. (Figure 6, it should be noted, does not even employ the effects of a lagged funds rate to capture the "interest rate smoothing" that the Committee unquestionably put in place along with its reaction to forecasts of inflation and real economic activity over virtually all of the decade of the 1970s [Orphanides, 2002]). The figure's Taylor rule uses Greenbook forecasts of inflation relative to an assumed 2 percent target and of real GNP relative to the real-time estimates of potential output, as described in Orphanides (2003b). Other than its reliance on forecasts and data available in real time to the FOMC for its policy deliberations, it follows Taylor's (1993) classic parameterization, including the coefficients he originally suggested for the Committee's responsiveness to inflation and the output gap and his assumption of 2 percent for the equilibrium real funds rate. Numerous studies over the past decade have suggested that adherence to such a policy rule should represent rather good, if not optimal, monetary policy and should be expected to deliver reasonably good macroeconomic performance. ${ }^{10} \mathrm{By}$ this rationale,

\footnotetext{
${ }^{10}$ See, for example, the studies in Taylor (1999).
} 


\section{Figure 6}

\section{Forecast-based Taylor Rule}

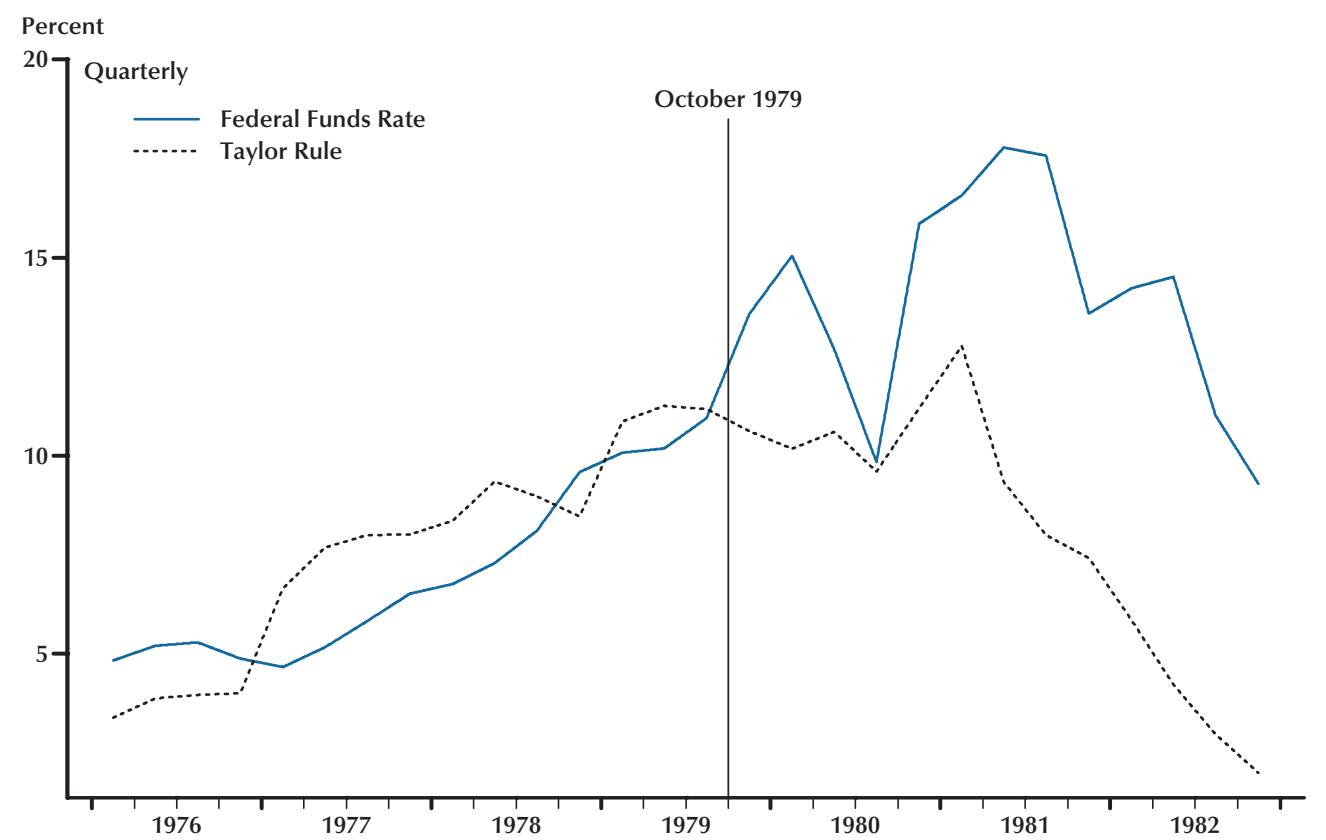

and since the Committee's actions up to the summer of 1979 line up well with the Taylor rule prescriptions, policy should have been considered successful. However, it is precisely this reasoning that highlights the fragility of supposedly efficient Taylor rule prescriptions. The strategy of exact adherence to this rule would not have delivered much better outcomes than the policy in place before the reforms of October. And adherence after October 1979 would have prevented the tightening necessary for controlling inflation. Adoption of the new operating procedures shifted policy away from the pitfalls of the unreliable guidance suggested by the Taylor rule.

\section{Point Seven}

Chairman Volcker explained in 1992 that he did not believe that he would have been able to get the FOMC to accept overtly the increase in the funds rate that ultimately proved necessary to rein in inflationary money growth.

[T] he general level of interest rates reached higher levels than I or any of my colleagues had really anticipated. That, in a perverse way, was one benefit of the new technique; assuming that those levels of interest were necessary to manage the money supply, I would not have had support for deliberately raising short-term rates that much. (Volcker and Gyohten, 1992, p. 170)

Indeed, Chairman Volcker realized this potential difficulty with deliberate tightening in real time. Greider wrote,

Early in his tenure, Volcker had directed the senior staff to begin technical studies on changing the Fed's basic operating method, and after the embarrassment of the board's 4-3 vote on September 18, Volcker pushed the idea more aggressively. (Greider, 1987, p. 105)

Joseph B. Treaster put the point slightly differently in his book published in 2004.

In the middle of his second month as Fed Chairman, Volcker began developing a strategy 
for implementing what would be the single most important decision of his career. His insight, triggered by the reaction to the close vote, was that as confident as he felt at the moment, there might very well be a point, before inflation had been stopped, at which a majority at the Fed would say, No more. "When you have to make an explicit decision about interest rates all the time," Volcker said years later, "people don't like to do it. You're always kind of playing catch-up. I wanted to discipline ourselves."

His solution, which now seems breathtakingly simple, was to take the cutting-edge decision out of the hands of the members of the Fed-or at least make it seem that way... (Treaster, 2004, pp. 147-48)

As Henry Wallich noted soon after the FOMC adopted the new procedures,

At the policy level, the reserve-based procedure has the advantage of minimizing the need for Federal Reserve decisions concerning the funds rate. Interest rates become a byproduct, as it were, of the money-supply process. (Wallich, 1980, p. 4)

William Greider quoted Governors Teeters, Rice, and Partee as to the desirability of automatic interest rate movements and their tendency to distance the outcome from the monetary authority's discretion.

"Under the new system," Nancy Teeters observed, "we could say what we were doing was concentrating on the monetary aggregates. It was perfectly obvious to me that if you set the money growth too low, that would send interest rates up. That was never in doubt. The problem with targeting the Fed Funds rate is that you had to set it. This did let us step back a bit."

Emmett Rice, who had joined the board four months earlier, had questioned interest-rate targeting himself, convinced that it would make more sense to control reserves directly..."This meant you were not directly responsible for what happened to interest rates. This was one of the advantages. If interest rates had to go to 20 percent-and I have to say that nobody thought they would go that high-then this would be the procedure doing it. I wouldn't call it a cover, but I don't think anyone on the committee would have been willing to vote to push interest rates as high as 20 percent. This was a way to achieve a result, a more effective way to get there."

Chuck Partee, the other reluctant "dove," was attracted to the operating shift by a different argument. Partee was not a monetarist himself, but he thought that the monetarist approach might overcome a flaw in the Fed's institutional reflexes-sticking stubbornly with a strong position too long and causing more damage to the economy than it had intended...

"It may sound odd, but I would prefer the evenhanded approach of the monetarists. I became very concerned about a mind-set that would lead us right in to a recession—get tight and stay tight...I found myself far less hostile to the notion that we might have a fairer approach by targeting the money supply than I was to the idea that we should raise interest rates one time and keep raising them. The problem is, there is also a hesitancy to reduce interest rates once they have been raised. My concern grew out of my reflection on several earlier recessions, particularly 1974-1975. My concern was that we would be slow to respond to weakness and permit a substantial contraction in money and credit to occur. There would be a great chance of that, that we might just get locked into a position of holding tight for a rather extended period.” (Greider, 1987, pp. 111-12)

\section{Point Eight}

Stephen Axilrod explained the import of the FOMC's implicit decision to renounce interest rate smoothing some 15 years after the new procedures were adopted.

[T]he Great Inflation [of the 1970s]...came about because of an interaction of a culture of extreme policy caution and a number of unanticipated changes in the economic environment. That is, in the culture of the time the policy instrument, say, the funds rate, was adjusted very carefully-slowly and in small increments...In that context you can think about the policy 
of 1979-82 as an effort to break the culture of extreme policy caution. (Axilrod, 1996, p. 23233)

\section{Point Nine}

After October 6, 1979, the FOMC set, and published in the policy record, short-run targets for money growth over the three months ending in the last month of the current quarter, based on the desired approach to the annual ranges that were announced in February and July in accord with the Humphrey-Hawkins Act. With the nonborrowed reserves path derived from these targets, along with the Committee's initial borrowing assumption, the evolution of the actual federal funds rate between FOMC meetings would depend primarily on money-stock developments relative to the targets over that period.

This process obviously has nothing to do with Committee estimates of the NAIRU or of the associated estimates of potential output, nor does it have anything to do with gaps of unemployment or output from "full employment" levels. Actually, from a money-demand perspective, outcomes for the growth of the money stock in the current quarter have more to do with the growth of output ending in the current quarter than with an output gap (see, in particular, Orphanides, 2003b, Section 2.5). As Orphanides has pointed out, misestimates of the NAIRU and potential output and the associated misestimates of the unemployment and output gaps were primary causes of the inflation of the 1970s (Orphanides, 2002, 2003a). Thus, it is understandable that the FOMC implicitly forswore gap analysis in the fall of 1979 (Orphanides, 2004; Orphanides and Williams, 2004).

Figure 7 provides a graphical illustration of the gap analysis-based dilemma. As seen in the middle panel, based on the available estimates of potential supply, actual output had fallen well short of potential output and the gap was projected to deteriorate even before the fears of recession appeared on the horizon in 1979. ${ }^{11}$ This slack

\footnotetext{
${ }^{11}$ Potential output is from Council of Economic Advisors (1979, p. 75). This estimate, which was prepared in February 1979, was also employed by the Federal Reserve Board staff as its estimate throughout 1979.
}

alone should have eventually led to a gradual easing of inflationary pressures, which can be seen in the forecast of inflation in the top panel. Throughout 1979, this reasoning suggested that holding back on tightening policy appeared to provide a reasonable balance of the Committee's objectives, affording gradual disinflation and economic expansion. In retrospect, the 1979 estimates of potential proved overly optimistic, explaining why the policy prescriptions from this gap-based analysis were overly expansionary. But this was not recognized at the time. Continued adherence to gap-based analysis would have prolonged the policy of inappropriate, even if inadvertent, monetary ease. The policy reform in October short-circuited this process.

\section{Point Ten}

The monetary policy process of short-run money targeting also is not explicitly dependent on the longer-term economic forecasts of the Board members and Reserve Bank presidents. Although their sense of the outlook implicitly could affect the Committee's money targets, initial borrowing assumption, and choice for the funds rate band, the influence of opinions about the future of the economy over the actual course of the federal funds rate is clearly less direct than with a federal funds operating target in which the Committee sets its operating objective based in important part on its opinion of the outlook.

This much looser connection between the stance of policy and the uncertain economic forecasts of FOMC members is, of course, consistent with Chairman Volcker's denigration of the accuracy of any economic forecasts that was cited above as well as Axilrod's earlier observation that after the adoption of the new techniques the FOMC avoided basing policy on forecasts. The new operating procedures, with their dependence on near-term outcomes for money, guaranteed that error-prone longer-term economic projections of both prices and real GNP would not interfere with the coming battle against virulent and entrenched inflation.

The Board staff's economic projection in mid1979 did not offer an accurate outlook for real growth. Figure 7 confirms that, by July 1979, the 
Figure 7

\section{Greenbook Monetary Policy Report Projections}

Inflation (GNP Deflator Growth Over 4 Quarters)

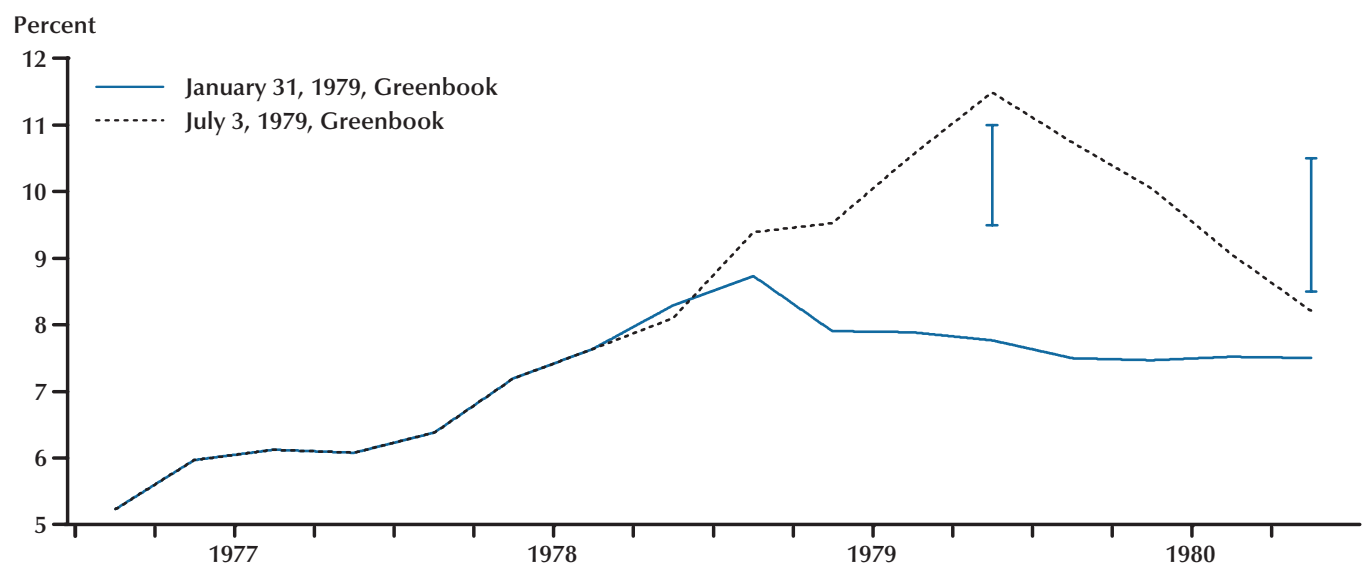

GNP

Billions (1972 dollars)

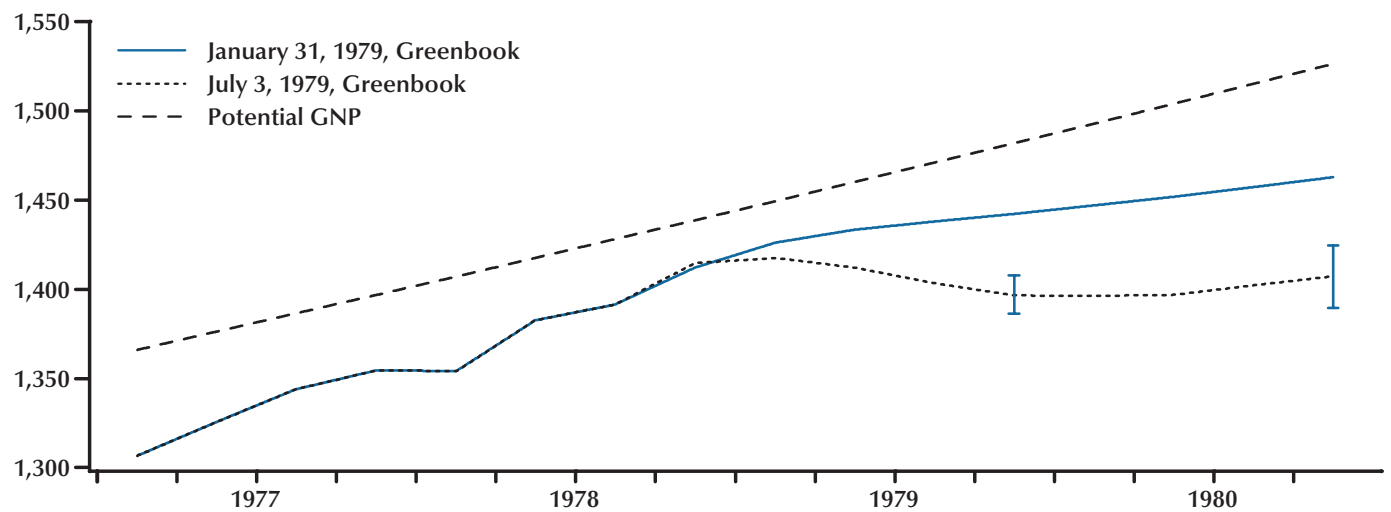

Unemployment Rate

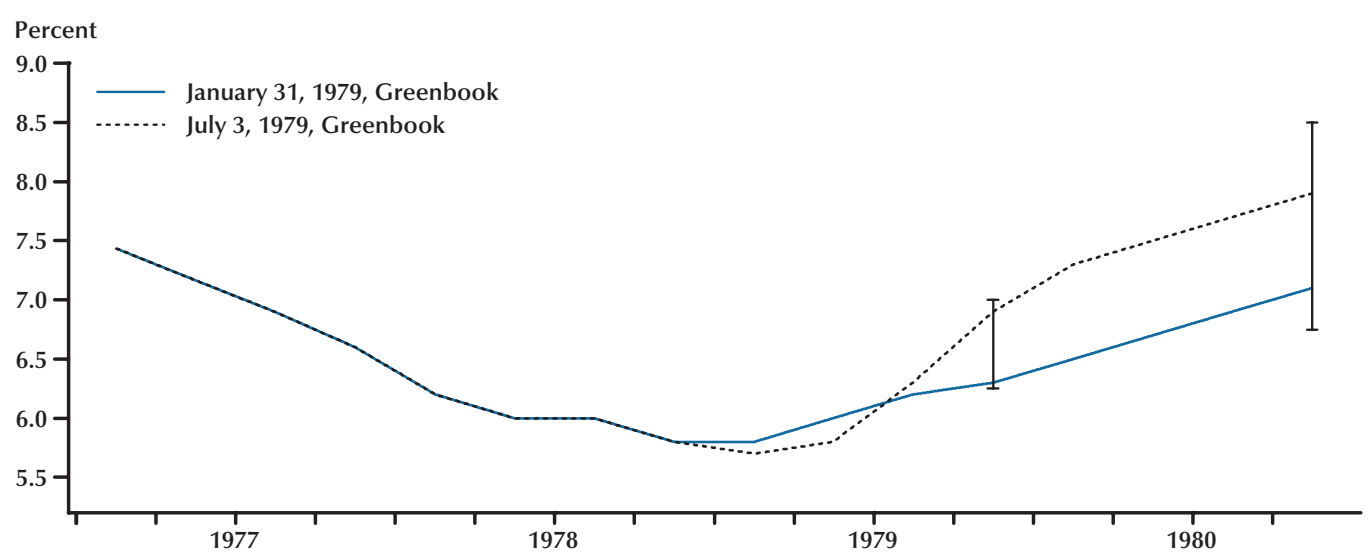

NOTE: Vertical line segments indicate range of Board consensus projections as presented in the July 17, 1979, Monetary Policy Report. 


\section{Figure 8}

\section{Inflation Forecasts and Outcomes (Three-Quarter-Ahead Growth in GNP Deflator Over Four Quarters)}

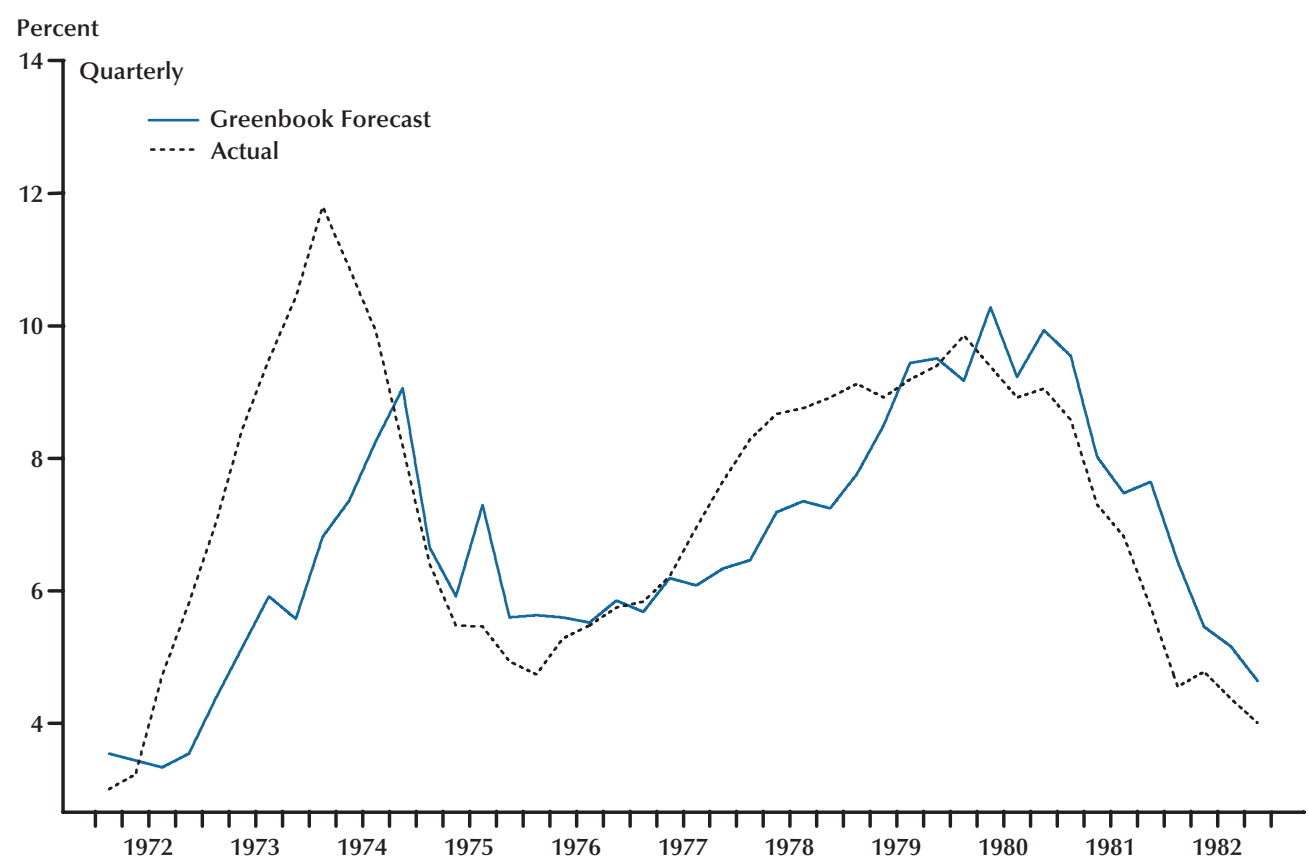

Greenbook was predicting that a recession had begun by the second quarter of 1979, as clearly shown by the forecasted decline in the level of real GNP through the end of the year. (In retrospect, real GNP instead is known to have registered positive growth in each quarter of that year.) The lower panel of Figure 7 displays the associated staff prediction of a sharp rise in unemployment through the end of 1980. As a result of the projections by the time of the July Greenbook, of steep increases in the output and employment gaps, along with moderating energy prices, average four-quarter deflator inflation was foreseen to abate appreciably in 1980, after spiking through 1979.

The staff had established a history of excessive optimism in forecasting inflation in the 1970s. Figure 8 demonstrates this record visually. It presents for the 1970s the successive underpredictions of the average four-quarter rate of inflation in the deflator in mid-quarter Greenbooks-plotted in the quarter of that Greenbook's publicationthree quarters in advance of the last predicted quarter, as in the Taylor rule noted in Point Six. The bias in the inflation forecasts, of course, is closely related to the overly optimistic measures of potential supply discussed in Point Nine. The inflation forecasts were systematically lower than they should have been simply because of the persistent perceptions of economic slack that was not actually there. The evidence had not yet been assembled showing that basing inflation forecasts on real-time estimates of the output gap may be unreliable (Orphanides and van Norden, 2003).

\section{Point Eleven}

With its actions on October 6, the Committee fully assumed its unique responsibility for the attainment of long-term price stability. To understand the nature of this change, it is necessary to discuss the attitudes of previous FOMCs.

Under Chairman Burns, the common thread 
running through many communications on monetary policy was that the Federal Reserve and other critical influences ultimately shared responsibility for the too-rapid rise in prices. Excessive fiscal deficits were a commonly referenced contributing source. The cost-push effect of union power through wage negotiations also was regarded as playing an important role, as was corporate discretion over administered product prices. After mid-decade, OPEC's cartel-like pricing was thought to influence not just relative prices but also overall trend inflation. By the 1970s, the economics profession had advanced sufficiently that most FOMC members had accepted a vertical long-run Phillips curve in which the equilibrium unemployment rate was independent of the inflation rate. Rather, despite rousing anti-inflationary speeches and testimony, the Federal Reserve had not really taken to heart its own sole responsibility for the average rate of inflation over the long pull. It is the central bank alone that has the duty of ensuring secular price stability, along with its other objective of promoting maximum employment or, relatedly, sustainable economic growth, in the intermediate term. These objectives were enshrined in the Federal Reserve Act in 1977.

Although he never mentioned this 1977 statutory addition, former Chairman Burns presented the 1979 Per Jacobsson lecture in Belgrade on September 30, entitled "The Anguish of Central Banking," in which he delved more deeply into the dilemma of monetary policymaking-attributing it to this fundamental factor:

the persistent inflationary bias that has emerged from the philosophic and political currents that have been transforming economic life in the United States and elsewhere since the 1930s. The essence of the unique inflation of our times and the reason central bankers have been ineffective in dealing with it can be understood only in terms of those currents of thought and the political environment they have created...

Inflation came to be widely viewed as a temporary phenomenon-or provided it remained mild, as an acceptable condition. "Maximum" or "full" employment, after all, had become the nation's economic major goal- not stability of the price level...Fear of immediate unemployment-rather than fear of current or eventual inflation-came to dominate economic policymaking...

Viewed in the abstract, the Federal Reserve System had the power to abort the inflation at its incipient stage fifteen years ago or at any later point, and it has the power to end it today. At any time within that period, it could have restricted the money supply and created sufficient strains in financial and industrial markets to terminate inflation with little delay. It did not do so because the Federal Reserve was itself caught up in the philosophic and political currents that were transforming American life and culture... (Burns, 1979, pp. 9, 13, 15)

Chairman Burns gave the following basic reason for why the role of the central bank in fighting inflation in a democracy would be "subsidiary" and "very limited," thus rendering it able to cope "only marginally" with inflation, causing him to think that "we would look in vain to technical reforms as a way of eliminating the inflationary bias of industrial countries" (Burns, 1979, pp. 21-22):

Every time the Government moved to enlarge the flow of benefits to the population at large, or to this or that group, the assumption was implicit that monetary policy would somehow accommodate the action. A similar tacit assumption was embodied in every pricing or wage bargain arranged by private parties or the Government. The fact that such actions could in combination be wholly incompatible with moderate rates of monetary expansion was seldom considered by those who initiated them, despite the frequent warnings by the Federal Reserve that new fires of inflation were being ignited. If the Federal Reserve then sought to create a monetary environment that fell seriously short of accommodating the upward pressures on prices that were being released or reinforced by governmental action, severe difficulties could be quickly produced in the economy. Not only that, the Federal Reserve would be frustrating the will of Congress-a Congress that was intent on providing additional services to the electorate and on assuring that jobs and incomes were maintained, particularly in the short run. 
Facing these political realities, the Federal Reserve was still willing to step hard on the monetary brake at times-as in 1966, 1969, and 1974-but its restrictive stance was not maintained long enough to end inflation...As the Federal Reserve...kept testing and probing the limits of its freedom to undernourish the inflation, it repeatedly evoked violent criticism from both the Executive establishment and the Congress and therefore had to devote much of its energy to warding off legislation that would destroy any hope of ending inflation. This testing process necessarily involved political judgments, and the Federal Reserve may at times have overestimated the risks attaching to additional monetary restraint. (Burns, 1979, pp. 15-16)

In essence, Burns suggested that if a central bank had committed the expansionary errors that generated inflation, as had happened in the late 1960s and 1970s in the United States, public and political support appeared necessary to maintain the much tougher policies that might be required to restore stability. Without such support, it could be questioned whether a central bank had the mandate for such action. Nonetheless, Burns ended his lecture on an optimistic note, observing that the political environment was indeed shifting in that direction.

When Chairman Volcker was appointed to the Board, public support of anti-inflationary action had become quite high, and political sentiment appeared much more conducive than ever before to strong actions resisting inflation. By the late 1970s, public opinion polls consistently identified inflation as a greater problem than unemployment. In any event, Chairman Volcker said in an interview on PBS's Commanding Heights (2000) that he had listened to and been much affected by this lecture by Chairman Burns before he returned to Washington. He thought that Chairman Burns was saying that as a practical matter the Federal Reserve was "rather impotent" in fighting inflation. While that might have been the case earlier in the decade, Chairman Volcker obviously disagreed that this assessment was still correct in 1979. In retrospect, he was right. The FOMC at the end of the day proved able to live up to its obligation of being responsible for establishing and maintaining stable prices over time.

\section{Point Twelve}

That a tightening of monetary policy could evoke "violent criticism" by "frustrating the will" of a Congress intent on "assuring that jobs and incomes were maintained," as Chairman Burns contended, can be supported from the contemporaneous statements about the economic goals of the elected officials themselves. For example, on October 19, 1979, the Senate majority leader, Robert C. Byrd, Democrat from West Virginia, declared the following:

Attempting to control inflation or protect the dollar by throwing legions of people out of work and shutting down shifts in our factories and mines is a hopeless policy. (Greider, 1987, p. 149)

As another example, Representative Henry S. Reuss, Democrat from Wisconsin, chairman of the House Committee on Banking, Finance, and Urban Affairs, said this after the four-to-three vote on the discount rate on September 18, 1979:

For the first time, Fed members are wondering out loud whether it really makes sense to throw men and women out of work, and businesses into bankruptcy, in order to "rescue the dollar" by chasing ever-rising European interest rates. (Berry, 1979, p. A1)

Although Representative Reuss was a general supporter of the new operating procedures, at Chairman Volcker's first Humphrey-Hawkins testimony on February 19, 1980, this is what he said:

Last year, following our first hearings, under the procedures established in Humphrey-Hawkins, we issued a report on March 12, 1979, agreed to by all except one of our members.

The key recommendation of that report was “anti-inflationary policies must not cause a recession."

So far, the Federal Reserve's policies have not caused a recession and for that, you deserve our appreciation...

The Federal Reserve cannot cure inflation with monetary shock treatment and it shouldn't try. (U.S. House of Representatives, 1980b, pp. 1-2)

In 1982, with the economy having slid into a recession, both Republicans and Democrats intro- 
duced legislation that would have required the Federal Reserve to keep real interest rates within the range of historical experience, which could have potentially interfered with the conduct of monetary policy in a damaging manner.

In Point Three above, we saw that the IMF noted "that it is evident that governments have felt severe economic and political constraints in launching an effective anti-inflation program, since in the short run this would be bound to have severe employment effects." Perhaps in part to circumvent those political constraints, the FOMC members appreciated that the new procedures distanced them from the setting of the funds rate, as Point Seven demonstrated, and Chairman Volcker's answer to the question about real-side impacts in the press conference on October 6, as quoted above, was sufficiently noncommittal that William Greider claimed that "he evaded the point and concealed his real expectations" (Greider, 1987, p. 123).

But these inferences inevitably enter into the realm of speculation, because the motivation of participants in the onrush of history is rarely specified at the time. Even so, it is difficult to escape the conclusion that potential criticisms of FOMC policy by politicians, who in coming years actually would show stirrings-by introducing legislation—of using their power to affect the FOMC's makeup or freedom of action, engendered in Committee members the desire to obscure their responsibility for real-side developments.

\section{"WHAT WE HAVE HERE IS A FAILURE TO COMMUNICATE!" - OR NOT!}

Indisputably, market participants were somewhat confused, especially early on, by what the new procedures were and what they portended for monetary aggregates and the money market, let alone for longer-term interest rates, real magnitudes, and inflation. One diagnosis would be to highlight a failure by the Federal Reserve to communicate the nature of its new policy approach soon enough and with enough specificity to satisfy the public's, and especially market participants', pressing desire to know. In particular, between
October 6, 1979, and February 1, 1980, the FOMC did not release any detailed summary of its new technique. In consequence, at its meeting on February $3-4,1980,{ }^{12}$ the SOMC held that

[t]he Federal Reserve should announce further details about its procedures to reduce the longrun trend of money growth and reestablish its credibility by actually achieving its announced targets. This would be the most effective way to eliminate the entrenched belief that the rate of inflation will continue to rise in the Eighties. (SOMC, 1980, p. 2)

Was one reason for this reticence that the FOMC was operating under a legacy of secrecy inherited from the tenures of Chairmen Martin, Burns, and Miller? (See, Goodfriend, 1986.) Could this tradition be used to explain, at least in part, why, for example, the Axilrod-Sternlight memorandum was not released immediately? Immediate release of this memorandum shortly after October 6 would have revealed, for all the world to see, a systematic, considered monetary policy approach.

An alternative diagnosis would be that existing contingences, inevitable complexities, the intended audience, and unavoidable uncertainties all posed severe challenges to clear communication, which could be surmounted only over time. As has already been seen in the historical record, the FOMC actually had adopted the new operating procedures on a temporary, contingent basis, awaiting evidence on just how effectively they would work given the uncertainties involved, including those regarding money demand (FOMC Transcript, 10/6/1979, pp. 9-10, 15). However, as Peter Sternlight learned, presumably to his chagrin, it is difficult to make the point initially that new procedures have "experimental" elements without seeming to undercut the resolve and understanding of the agency implementing them. As the rational expectations revolution has emphasized, a "permanent" commitment has a much more powerful effect on expectations than a "temporary" one. To be sure, the FOMC did not

\footnotetext{
${ }^{12}$ The SOMC meeting was on Sunday, February 3, 1980, so the members of the committee were not aware of the attachment to Volcker's February 1 Joint Economic Committee testimony.
} 
stress publicly the contingent nature of its adoption of the new operating technique. Still, the Committee did not discuss and reaffirm its earlier tentative decision to adopt the new approach until it met on January 8, 1980. Only afterward was Chairman Volcker ready to release publicly the "technical" description of the new procedures, which he did on February 1, 1980.

In addition, the new procedures, without question, were complex. The Axilrod-Sternlight memorandum, which describes the essence of the new procedure, was composed as a background paper presenting a policy choice to the FOMC, for which their writing was well suited. It certainly was not written with the simplicity and pedantry needed for public consumption. Financial market participants are trained and paid primarily to buy low and sell high.

Admittedly, they have a longer attention span for digesting, and a greater capacity to grasp, Federal Reserve analyses describing the intricacies of monetary policymaking than does the public at large. But even with a hypothetical manual containing a perfect prediction and complete elucidation of what the new procedures would be and how they would work, it is probable that market participants would have been able to assimilate the main features of those procedures only gradually from practical experience.

Furthermore, certain features simply could not have been known by the Federal Reserve in advance. Although the basic procedures had been considered before their approval on October 6, 1979, some elements could not have been settled except through the passage of time. Initially, these inherently uncertain, and thus imperfectly describable, features included (i) how aggressive the FOMC would be in setting and varying the monetary target paths, the initial borrowing assumption, and the band for allowable funds trading; (ii) how extensive intermeeting policy-related adjustments to the nonborrowed reserves target path would be; (iii) how extensive intermeeting technical "multiplier" adjustments to the nonborrowed reserves target path would be; and (iv) how responsive the monetary aggregates, the real economy, and inflation would be to these various ministrations.
FOMC communication, operating within this context, naturally had the obligation to strive for maximum conciseness and clarity; but in judging the Federal Reserve's success in public communication in this case, especially late in 1979 and early in 1980, a historian must carefully parse the words used by the principals. Take as an example the interview that appeared in the WSJ on October 11, in which a contemporary reader may not consider the "Fed official" to be a paragon of clear communication (see p. 206). But such a reading risks misinterpreting the meaning of the words used in what arguably was an informative description of a complex, responsive, and discretionary monetary policy approach.

First, a "rule of thumb" was meant to convey something that the Federal Reserve certainly was not going to propound: an oversimplified summary of a complex underlying system. Second, at the time, the word "rule" by itself had a different meaning than it does today because John Taylor's famous usage, which has been adopted by the profession, has altered its definition among economists to mean merely a "guideline" subject to judgmental overthrow. Then, the word "rule" had been used influentially by Milton Friedman in the "rules versus discretion" debate to mean a legislated requirement that would have to be followed strictly. Besides "nondiscretionary," a "rule"-also unlike today's sense-was "nonresponsive" to current business cycle developments as well, as in Friedman's k-percent money growth rule or Allan Meltzer's monetary base growth rule. Only later did Allan Meltzer and Bennett McCallum introduce and advocate variable base growth in a nondiscretionary rule, explicitly employing the concept of a "responsive, nondiscretionary rule" (Meltzer, 1987; McCallum, 1988). Third, the word "unpredictable" apparently did not pass the Fed official's lips; instead, it was the reporter's word, although Chairman Volcker did believe that some "uncertainty" about future monetary policy settings could be useful in curtailing "speculation" (Volcker and Gyohten, 1992, p. 170). Finally, today's vantage point makes it clear-although it may have been less clear in the interview - that the "Fed official" was saying, not that a thought-out systematic structure of the 
new procedures did not "exist" (since it certainly did in the Axilrod-Sternlight memorandum), but rather that the Federal Reserve's "future behavior" hadn't taken place and obviously couldn't yet be pictured in detail. Only the passage of time could clarify the emerging contours of the operational landscape.

\section{WAS CHAIRMAN VOLCKER...}

In attempting to draw lessons for the present day from the October 1979 policy reform, it seems necessary to classify the essential characteristics that made Chairman Volcker's FOMCs successful at fighting inflation and setting the stage for Chairman Greenspan's FOMCs to finish the job. This section addresses the questions of whether Chairman Volcker was (i) a monetarist? (ii) a nominal income targeter? (iii) a new, neo, or oldfashioned Keynesian? (iv) an inflation targeter? or (v) a great communicator?

\section{A Monetarist?}

Chairman Volcker's scientific views on the merits and demerits of the doctrine of monetarism arguably changed little during his years as President of the New York Federal Reserve Bank and Chairman of the Board of Governors, judging by various FOMC transcripts, speeches, and testimony. As already seen, he subscribed to the longrun connection between average money growth and inflation, although some (but not all) nonmonetarist macroeconomists at the time would have agreed with this secular linkage. He also expressed this point of view in September 1976, when he presented an extended analysis of monetarism to an academic audience. He first characterized the school not only as having correctly insisted that money matters but also as having

usefully emphasized the danger of confusion between nominal and real rates and the role of price expectations. They have forcefully made the case for the view that in the long run velocity is not related to the stock of money and that, in the same long run, an excess supply of money contributes not to real income or wealth but simply to inflation. (Volcker, 1976, p. 25152.)
However, he then prophetically noted that

no one should be under the illusion that any tactical change will end controversy that, in the last analysis, stems more from different judgments about relevant policy variables than about operating techniques. (Volcker, 1976, p. 253)

He outlined many of the disadvantages to money targeting that in the second half of 1982 would ring the death knell, though admittedly at first in a muted way, to monetary targeting at a low growth rate:

[This points out] the simple fact that, whatever the stability in the relationship between money and nominal income in the longer run, there is considerable instability in the relationship over time horizons relevant to policymakers. Certainly the relationships between money, interest rates, and nominal income have been unusual over the year or so since I rejoined the Federal Reserve...I can only conclude that, in periods such as that we have just been through, we need to be alert to possible shifts in the demand for money. (Volcker, 1976, p. 252)

He continued as follows:

[W]e must constantly balance the danger of underreacting to deviations of the aggregates from target paths against the danger of overreacting...Clearly, there are risks in not responding to bulges or shortfalls in the money supply relative to objectives...

But the danger of overreacting to deviations in the aggregates from targets is just as real... Attempts to respond immediately to shifting reserve availability and allowing the money market abruptly to tighten or ease could therefore easily result in whipsawing of the market... Since only a relatively small fraction of the impact of a given move in reserve availability or money market conditions is reflected in the behavior of the monetary aggregates in the short run, very large movements in reserves and money market conditions might be needed to correct short-run aberrations. Worse, the lagged effect of these moves might then have to be offset by even larger movements in the opposite direction in the subsequent period-a process 
that could easily lead to a serious disruption of the whole mechanism. (Volcker, 1976, p. 254)

He argued that if a central bank turns toward significant monetary restraint, it can induce difficult reactions on the real side, with broader ramifications.

It is hardly a satisfactory answer to say that central banks in principle can always resist inflationary pressures by simply refusing to provide enough money to finance them. Set against persistent expansionary pressures, aggressive wage demands, monopolistic or regulatory patterns that resist downward price adjustments, and other factors affecting cost levels, such an approach would threaten chronic conflict with goals of growth and employment that must rank among the most important national objectives. In a democracy, the risk would not be just to the political life of a particular government, but to our way of government itself...

In this larger social and political setting, we should perhaps think of central banks themselves as "endogenous" to the system. A theory of chronic inflation that points only to the money supply is not going to prove adequate to understand-or deal with-inflation in today's world. The danger is that it may discourage the search for particular remedies for particular problems...

The monetarists, emphasizing old truths in modern clothing, have provided a large service in redressing the balance. It is in pressing the point to an extreme that the danger lies-the impression that only money matters and that a fixed rate of reserve expansion can answer most of the complicated problems of economic policy. (Volcker, 1976, p. 255-56)

As to the monetarist arguments on technical issues of operating procedures, he also articulated positions that foreshadowed the FOMC's side in future debates and in the Staff Study in 1981.

While I do not pretend to econometric expertise, I do know that a massive amount of research has been conducted in this area. The apparent result is that the relationship between money and reserve aggregates, particularly in the short run, appears no more reliable than the relationship between interest rates and money...

We have techniques to make the needed forecasts with both the interest rate and reserve approaches. The trouble is that the forecast errors are large no matter what procedure is used, particularly over periods of one to three months. Indeed, unimpressive as they are, I am told some of the correlations observed in the historical data between reserve measures and monetary measures would prove to be spurious under a regime of rigid reserve targeting. (Volcker, 1976, p. 253-54)

When the entire 13-paper Staff Study (BOG, 1981) was published, the Federal Reserve gave the results a lot of play, ranging from an extended discussion in the February 1981 HumphreyHawkins report, to a press conference, to two conferences for economists (the conference for academic economists was April 17, 1981, with lead-off statements from Karl Brunner and Stephen Goldfeld, and the conference for market economists was April 21, 1981), to a Federal Reserve Bulletin article by Stephen Axilrod (1981).

Monetarists did not believe that the FOMC had gone nearly far enough in the reforms of October 1979 and seized on the Staff Study to reiterate their points. Milton Friedman critically reviewed the experience (Friedman, 1982). Peter Sternlight and Stephen Axilrod vied in person with Robert Rasche and Allan Meltzer in a heralded debate on April 30, 1981, at The Ohio State University (Rasche et al., 1982). Even so, two of the Staff Study's papers were published by Karl Brunner, editor of the Journal of Monetary Economics. ${ }^{13}$ In addition, at a conference held at the Federal Reserve Bank of St. Louis in October 1981, David E. Lindsey was asked to examine the institutional changes needed to improve control of the money stock. ${ }^{14}$

Even during the period of monetary targeting, Chairman Volcker made his skeptical opinion of monetarism plain, first to Congress and then later to his FOMC colleagues.

\footnotetext{
13 Tinsley, von zur Muehlen, and Fries (1982); Lindsey et al. (1984).

${ }^{14}$ See Lindsey (1983).
} 
Chairman Volcker...I would remind you that nothing that has happened-or that I've observed recently-makes the money/GNP relationship any clearer or more stable than before. Having gone through all these redefinition problems, one recognizes how arbitrary some of this is. It depends on how you define [money]. (FOMC, Transcript, 1/8-9/1980, pp. 13-14)

Finally, the FOMC's departure from lowgrowth monetary targeting after mid-1982, and the subsequent downgrading of M1 itself as well as replacement of nonborrowed reserves with borrowed reserves in the fall of that year, which are beyond the scope of this paper, suggest as well that Paul A. Volcker did not qualify as a monetarist.

\section{A Nominal Income Targeter?}

Nominal income targeting was in the air in the late 1970s and early 1980s in the writings of James Tobin, Bennett McCallum, Robert Gordon, and others. In a sense, money and nominal income targeting could be viewed as closely related. Indeed, to emphasize this point, James Tobin even referred to GNP targets as "velocity adjusted aggregates" (Tobin, 1985). Thus, the following quotation from Chairman Volcker's 1981 HumphreyHawkins testimony perhaps could be read as the statement of a closet nominal-income targeter:

I would like to turn to the targets for 1981. Those targets were set with the intention of achieving further reduction in the growth of money and credit, returning such growth over time to amounts consistent with the capacity of the economy to grow at stable prices. Against the background of the strong inflationary momentum in the economy, the targets are frankly designed to be restrictive. They do imply restraint on the potential growth of the nominal GNP. If inflation continues unabated or rises, real activity is likely to be squeezed.

As inflation begins noticeably to abate, the stage will be set for stronger real growth.

(Volcker, 1981, pp. 5-6)

However, this interpretation would be inaccurate. To be sure, monetary targeting would con- strain the growth of nominal GNP, which is what Chairman Volcker was pointing out. But literal nominal GNP targeting would not have met with his approval, at least in the environment facing the Committee in 1979, for two reasons at a minimum.

First, a more directly controllable intermediate target than GNP was necessary to restore the public's confidence in the Federal Reserve's commitment to conquering inflation. While policy could be adjusted to maintain M1 growth within an announced range over relatively short periods, thus demonstrating that the Federal Reserve meant business, that could not be said of a nominal GNP target. The lags in the transmission process were, as they remain, too long, uncertain, and variable for that purpose, and too many other factors outside a central bank's control influence nominal income over short intervals. Second, nominal income targeting would not have represented as stark a break from the gradualist policies of the past as the Committee must have felt was necessary. As described by Tobin, and in light of the policy lags involved, nominal income targeting would require the central bank to continue to fine-tune the stance of policy on the basis of predictions of the future, hardly a recipe for success given the profession's sad forecasting record earlier in the 1970s. Stephen Axilrod later offered the following summary regarding the superiority of monetary targets:

A money supply guide has two virtues: the central bank can be held reasonably responsible and accountable for its achievement, and it will serve as an anchor to the windward against erroneous assessments of ongoing and predicted economic and price developments. (Axilrod, 1985, p. 600)

In 1979, Chairman Volcker himself clearly put predominant priority on conquering inflation. Nominal GNP targeting did not appear as certain a strategy for gaining the public's confidence and for fairly promptly achieving that goal as monetary targeting did.

\section{A New, Neo, or Old-fashioned Keynesian?}

A basic policy recommendation arising from the Keynesian framework, old, new, and neo, is 
that policy can be successful in stabilizing the economy by aiming to align aggregate demand with the nation's potential supply. In one sense, the theoretical argument behind this reasoning is impeccable, under the assumption that the implied policy prescription can be applied in practice. But Volcker rejected the premise that policy should actively seek to close output or unemployment and related gaps, judging that the informational requirements of such calculations were simply untenable.

The original Taylor rule, which used outcomes for the estimated output gap, that is, actual output less potential output, provides a useful illustration of the gap-closing Keynesian perspective. But unlike this Taylor rule, the reaction function consistent with targeting money growth instead, from a money-demand perspective, would use outcomes for estimated output growth. That is, whereas the Taylor rule stresses the role of the output gap for setting policy, a reaction function for controlling money growth would instead stress the growth rate of output relative to that of potential-that is, the change in the output gap. And indeed, estimated policy reaction functions suggest that, while Federal Reserve policy appeared to respond to such gaps quite strongly before Volcker became Chairman, this was no longer the case afterward (Orphanides, 2003b, 2004).

Because he had little tolerance for gap analysis, it is clear that he should not be placed in any of these camps. It is less certain that these camps were any more tolerant of inflation than he was, but he obviously had a very low tolerance for inflation.

\section{An Inflation Targeter?}

Does that mean that he anticipated today's advocates of inflation targeting, such as Governor Ben Bernanke, Thomas Laubach, Rick Mishkin, Adam Posen, and the current IMF or the central bank practitioners in New Zealand, Australia, Canada, England, Sweden, Korea, Poland, and South Africa? ${ }^{15}$ Not really, to the extent that they attempt to heighten central bank transparency through an announced, explicit numerical target

${ }^{15}$ See Bernanke et al. (1999). or range for the inflation rate. Instead, in a speech before an audience of academics in 1983-jocularly called "Can We Survive Prosperity?"16_ Chairman Volcker proposed a qualitative definition of price stability.
A workable definition of reasonable "price stability" would seem to me to be a situation in which expectations of generally rising (or falling) prices over a considerable period are not a pervasive influence on economic and financial behavior. Stated more positively, "stability" would imply that decision-making should be able to proceed on the basis that "real" and "nominal" values are substantially the same over the planning horizon-and that planning horizons should be suitably long. (Volcker, 1983, p. 5)

His disdain for forecasts as a policymaking tool also would have turned him against some recent practices for attempting to attain an inflation target. All things considered, he certainly didn't sound like a prototypical inflation targeter.

\section{A Great Communicator?}

In his days as president of the New York Federal Reserve Bank, he referenced approvingly the degree of openness in the policy record:

I might note in passing that the amount of information provided in these records probably sets a standard among the major central banks in the world, and represents a degree of openness entirely unknown to a central banker of an earlier generation. (Volcker, 1976, p. 253)

Chairman Volcker advanced the case for effective communication early in his tenure at the Board, as well as the advantages of monetary targeting in this regard.

All of this puts a special burden on those of us developing and implementing policy to "get it right," to communicate our purposes and intentions effectively, and to persevere with needed policies.

In that context, I am satisfied that the greater

\footnotetext{
${ }^{16}$ Early in the preparation process for this speech, he even more jocularly suggested the following title: "What Economists Don't Know-That Can Hurt You!” (David Lindsey's recollection.)
} 
emphasis we have placed on monetary targeting in recent years, supplemented by the change in operating techniques, has assisted both in communicating what we are about and achieving the internal discipline necessary to act in a timely way. (Volcker, 1980f, p. 6)

For the not-quite-three years of serious (if not always effective) short-term monetary targeting, FOMC communication indisputably was more transparent than in the surrounding years, when the FOMC did not intend for its communication to be very open-and succeeded admirably in realizing its intention. Despite the transparency under monetary targeting, the Committee was accused of adopting the new operating procedures only as a smokescreen to obscure its intention to markedly increase short-term interest rates. We have found no evidence to substantiate this claim and therefore consider it invalid. Instead, what does make for a fascinating debate, as there are two legitimate sides, is whether the Committee's communication during the period of monetary targeting moved toward openness as completely as it should have. In what follows, we try in a single discussion to give the flavor of each side of the debate.

The fanfare surrounding the announcement of the new procedures, the testimonies of Chairman Volcker and other Board members, the speeches by Board members and Reserve Bank presidents, the Humphrey-Hawkins reports, the official staff studies, the Bulletin article, and the unofficial staff papers must have served a communications end. The general principles underlying the new approach were well explained, and the FOMC, if only by dint of repetition, must have gotten these messages across over time, at least to some extent.

To be sure, the Committee convinced most observers that it meant business in large measure only by successfully reducing actual inflation as time went on. Survey responses regarding inflationary expectations and long-term interest rates did not respond immediately to the Federal Reserve's new operating procedures and associated stirring words; instead, it took some years, along with the reduction in actual inflation, for them to come down on a sustained basis. Market partici- pants understandably would have been somewhat skeptical initially that real reforms would continue when the going got rough, so they needed to see the lower inflation results before they would fully believe that a "regime change" had occurred. Whether publicly quantifying its inflation goal would have allowed the FOMC to shorten this period of adjustment can be debated. In any event, observers on the outside from the beginning could see the new operating procedures working themselves out in money markets as advertised in those Federal Reserve descriptions. While the Federal Reserve did not publish its short-run target paths for M1 and reserves, let alone the Federal Reserve's daily balance sheet or the reserve factor forecasts made by staff at the Trading Desk and the Board, most people on the outside did not care to know about the detailed plumbing of the new monetary control procedures. ${ }^{17}$ Instead, they just wanted to be sure that those on the inside were in fact minding the store and would "get it right," in Chairman Volcker's phrase.

The communications problems that did emerge concerned the public's basic understanding of exactly what constituted "getting it right," because effective monetary targeting proved to be no easy matter. Although beyond the scope of this paper, the increasing challenges of monetary targeting and the eventual departure from it via a nonborrowed reserves-based operating procedure, whatever the departure's merits or demerits, in Chairman Volcker's mind clearly could not be discussed openly-despite its only temporary adoption in the first place-perhaps partly in light of the favorable public comments the FOMC had made about the approach.

This brings us to the basic question of whether Chairman Volcker could be classified as a great, or even mediocre, communicator? One aspect of this question in turn can be decomposed thusly: Was communication about the future stance of policy transparent, and why or why not? Was

\footnotetext{
${ }^{17}$ At the January 1980 FOMC meeting, President Roos asked about heightening market knowledge and "dynamism" by releasing the reserve paths publicly. Peter Sternlight replied that intermeeting adjustments to those paths would only sow confusion if the quantitative process were carried out in public. He said, though, that more explanation of the "general methodology" would be warranted (FOMC, Transcript, 1/8-9/1980, pp. 9-10).
} 
communication about the present stance of policy transparent, and why or why not?

The first component question is the easier to answer. As a simple matter of pure logic, knowing and revealing publicly anything about the future stance of policy requires knowledge not only about the FOMC's ultimate objectives and future reaction function but also about the outlook for economic activity and inflation. As the historical narrative repeatedly demonstrated, Chairman Volcker was not just skeptical about but almost dismissive of economists' attempts to forecast the future. Indeed, he expressed the view that basing policy on such efforts had proven to be a counterproductive strategy in the 1970s. Given that attitude, he certainly would not have wanted the central bank to suffer the indignity of having its public statements about its own future policy stance, which necessarily would have had to rest on those same error-prone forecasts, frequently proven wrong by the march of events. This was obviously the case during the episode of monetary targeting. Even after the fall of 1982, when the Committee was instructing the Desk to pursue a borrowing operating target, the FOMC did not try to hint at what the future level of borrowing might be.

The answer to the second component question, about publicly describing the current policy stance, is much more difficult to prove-though not to provide-because it is necessarily more speculative. People tend not to express "politically incorrect" sentiments-to use the term former Governor Laurence Meyer has recently employed in a different macroeconomic context-on the record for historians later to uncover (Meyer, 2004, pp. 75-76). Thus, much of what follows cannot be conclusively demonstrated, but is based on the "atmospherics" around the Board in the 1980s (David Lindsey's recollection). A major role was played by political threats to FOMC independence, which also is largely beyond the scope of this paper, as is politicians' switch to deploying an altogether different strategy in the first half of the 1990s, which involved certain issues of transparency, and naturally induced an alternative defensive posture by the Federal Reserve. The post-1982 threats to Federal Reserve indepen- dence came from members of both parties in the Congress and fed back on the lack of transparency of the Federal Reserve under Chairman Volcker. Particularly in the post-monetary-targeting portion of his tenure as Board Chairman, the FOMC was guarded in its communicative detail. Indeed, the FOMC of this period revealed its propensity for "constructive ambiguity," a term that always could be used in polite company. A less-inhibited modern observer instead might call the Committee "opaque" or, even worse, "non-transparent."

Actually, what is not so transparent to the modern observer was precisely the Committee's defensive motivation at the time. An important concern was to avoid criticism, which could well have resulted in political pressure, which in turn could well have adversely affected the conduct of monetary policy. It is worth remembering that congressional criticism of what would now be termed sound, anti-inflationary monetary policy was not uncommon at the time. Sharp criticism of interest rate hikes by politicians, who ultimately might be successful in passing legislation altering the Federal Reserve's makeup or limiting its maneuvering room, would only render an already difficult decision to tighten even more difficult.

Without transparency, a decision that likely or certainly would have raised the funds rate, but not the discount rate, would not have been known even to the market cognoscenti any earlier than the next day through the signals imparted by the operations of the Trading Desk. And the action might or might not have been covered in financial news stories on the business pages of the newspapers, but not before the day after that. By then the news would have been sufficiently outdated that few politicians would have bothered to comment in real time.

By contrast, with the transparency of, for example, an immediate announcement of a change in the stance of policy, reports by the media would have been immediate. Commentators, including politicians, would have given their reactions on camera the same afternoon. The story would have been covered in the television news programs that evening and then would have appeared on the front pages of the major newspapers the next day. In other words, transparency would have 
transformed the action from a little-noticed technical adjustment in the obscure market for bank reserves into a big deal. In the resulting goldfish bowl, tightening would have been harder to decide to do-yielding worse monetary policy and hence inferior national economic results.

In light of these considerations, Volcker's advice to a "new central banker," as recounted by Mervyn King, is entirely understandable:

When I joined the Bank of England in 1991, I was fortunate enough to be invited to dine with a group that included Paul Volcker. At the end of the evening I asked Paul if he had a word of advice for a new central banker. He repliedin one word-“mystique." That single word encapsulated much of the tradition and wisdom of central banking at that time. (King, 2000)

This advice is, of course, not that of a great communicator.

\section{Summary}

The fundamentally negative answers to the last several questions imply that Chairman Volcker cannot readily be pigeonholed. To be sure, he unswervingly held to the end of vanquishing inflation. However, he was pragmatic in his choice of means. Paul A. Volcker, whose FOMCs went much of the way to conquering inflation, was a true original.

\section{CONCLUSIONS}

Inflation was well entrenched in the United States by the time President Carter appointed Paul Volcker Chairman of the Federal Reserve in 1979. For more than a decade, the Federal Reserve had attempted to cure the problem with a seemingly appropriate gradualist approach. By nudging short-term interest rates in small steps, monetary policy could be sufficiently expansionary to support reasonably high employment and growth, thereby avoiding recession, while at the same time restrictive enough to maintain some slack in aggregate demand, thereby making progress on inflation. In theory, by focusing on short-run demand management, both economic stability and gradual progress on inflation could be attained. Instead, this approach delivered instability and an ever-worsening inflationary psychology.

In 1978, Paul Volcker had already recognized that an approach placing greater emphasis on controlling inflation, instead of the strategy in place, would be more fruitful.

Wider recognition of the limits on the ability of demand management to keep the economy at a steady full employment path, especially when expectations are hypersensitive to the threat of more inflation, provides a more realistic point for policy formulation. So do the increasing, and in my mind well-justified, concerns with the problem of inflation by the national administration and by the citizenry. (Volcker, 1978, pp. 61-62)

Throughout the first half of 1979, Volcker was part of a vocal minority on the FOMC noting that the inflationary situation was approaching crisis proportions. But agonizing fears of recession kept the majority in Chairman Miller's FOMC from tightening policy to the extent necessary to contain inflation. President Carter's nomination of Paul Volcker to be Chairman of the Federal Reserve in late July started to shift this balance. But by late September 1979, the FOMC came to face the underlying crisis that Paul Volcker had worried aloud about since the first FOMC meeting of the year: mounting inflationary momentum and accompanying heightened inflation expectations. In addition, a policy crisis had recently emerged as well, whose proximate trigger was the reaction in the media and commodity markets to the four-to-three split of the Board of Governors in its discount rate vote on September 18. Prior to that vote but after his nomination as Chairman on July 25, Volcker had been portrayed in the media as an invincible general leading the war against inflation. By contrast, in its reporting on the discount-rate vote, the media pictured Volcker as a general whose troops, if not deserting, were in major retreat. Jumps in commodity prices also revealed that the FOMC had lost credibility regarding its commitment to an anti-inflationary policy.

A "strategic plan" was required that would restore the public's faith in the FOMC and contain 
"inflationary psychology." It had become clear to the FOMC that the "plan" had to be made public, break dramatically with established practice, allow for the possibility of substantial increases in shortterm interest rates, yet be politically acceptable, and convince financial market participants and people more generally that it would succeed. The new operating procedures, focusing on using nonborrowed reserves to keep monetary growth within the announced ranges for the year, satisfied these conditions. The available record does not suggest that the FOMC was converted to monetarist ideology. The "monetarist experiment" of October 1979 was not really monetarist! Rather, the new techniques were conditionally adopted for pragmatic reasons-there was a good chance that they would succeed in restoring stability. In essence, the Committee accepted that, under the prevailing circumstances, controlling monetary growth presented a robust approach to taming inflation. The "plan," while undoubtedly not perfect, turned out to be pretty good. It accomplished its major objectives of reversing rising inflationary expectations and taking the crucial initial steps in a two-decade-long journey back to price stability. And, perhaps as important, it instilled a focus on controlling inflation and inflationary expectations as an enduring aspect of Federal Reserve monetary strategy.

\section{REFERENCES}

ABC News' Issues and Answers. Transcript. October 29, 1979.

Allen, John H. "Bond Prices Score Strong Gains." New York Times, September 20, 1979, p. D9.

Axilrod, Stephen H. "New Monetary Control Procedure: Findings and Evaluation from a Federal Reserve Study.” Federal Reserve Bulletin, April 1981.

Axilrod, Stephen H. "Consequences and Criticisms of Monetary Targeting: Comment." Journal of Money, Credit, and Banking, November 1985, 17(4, Part 2), p. 60.

Axilrod, Stephen H. "Comment" in Financial Sectors in Open Economies: Empirical Analysis and Policy Issues. Washington, DC: Board of Governors of the Federal Reserve System, 1990.

Axilrod, Stephen H. "General Discussion" presented at the symposium Achieving Price Stability, sponsored by the Federal Reserve Bank of Kansas City, 1996.

Axilrod, Stephen H. and Lindsey, David E. "Federal Reserve System Implementation of Monetary Policy: Analytical Foundations of the New Approach." American Economic Review, Papers and Proceedings, May 1981, pp. 246-52; presented at the American Economic Association Meeting, Denver, CO, September 6, 1980.

Axilrod, Stephen H. and Sternlight, Peter. "Proposal for Reserve Aggregates as Guide to Open Market Operations," October 4, 1979, Memorandum to the Federal Open Market Committee, in Federal Open Market Committee, Transcript, Conference Call. Washington, DC: Board of Governors of the Federal Reserve System, October 5, 1979.

Bennett, Robert A. "Reserve Board, by 4-3, Raises Rate on Loans to Banks to Record 11\%." New York Times, September 19, 1979, p. A1.

Bernanke, Ben S.; Laubach, Thomas; Mishkin, Frederic S. and Posen, Adam S. Inflation Targeting: Lessons from the International Experience. Princeton, NJ: Princeton University Press, 1999.

Berry, John. "Fed Lifts Discount Rate to Peak 11\% on Close Vote.” Washington Post, September 19, 1979, p. A1.

Board of Governors of the Federal Reserve System. Minutes. Washington, DC: various dates.

Board of Governors of the Federal Reserve System. 66th Annual Report of the Board of Governors, 1979. Washington, DC: 1979a.

Board of Governors of the Federal Reserve System. Greenbook for the February 6, 1979, meeting. Washington, DC: January 31, 1979b. 


\section{Lindsey, Orphanides, Rasche}

Board of Governors of the Federal Reserve System. Bluebook. Washington, DC: February 2, 1979c.

Board of Governors of the Federal Reserve System. Press Release. Washington, DC: October 6, 1979d.

Board of Governors of the Federal Reserve System. Transcript of Press Conference. Washington, DC: October 6, 1979e.

Board of Governors of the Federal Reserve System. New Monetary Control Procedures. Volumes I and II, Federal Reserve Staff Study. Washington, DC: February 1981.

Brunner, Karl. “The Dilemma of Inflationary Policies.” Position paper prepared for the 9th meeting of the Shadow Open Market Committee, September 19, 1977.

Burns, Arthur F. "The Anguish of Central Banking." Per Jacobsson Lecture, Belgrade, Yugoslavia, September 30, 1979.

Carter, Jimmy. White House Statement, October 6, 1979, in Public Papers of the Presidents of the United States: Jimmy Carter, 1979. Book II. Washington, DC: Government Printing Office, 1980.

Commanding Heights. PBS Interview with Paul Volcker, Transcript, September 26, 2000, http://www.pbs.org/wgbh/commandingheights/ shared/minitextlo/int_paulvolcker.html.

Council of Economic Advisors. 1979 Economic Report of the President. Washington, DC: 1979.

Clark, Lindley H. Jr. "The Monetarists Grow Wary." Wall Street Journal, October 12, 1979, p. 22.

Conderacci, Greg. "Fed Warns That Unpredictable Posture Will Continue as Part of Its Policy Switch." Wall Street Journal, October 11, 1979, p. 3.

Cowan, Edward. "High-Interest Foes Fear Deeper Slump.” New York Times, September 20, 1979, p. 1.

Federal Open Market Committee. Transcripts. Washington, DC: Board of Governors of the Federal Reserve System: various dates.
Federal Open Market Committee. Briefing. Washington, DC: Board of Governors of the Federal Reserve System: May 22, 1979a.

Federal Open Market Committee. "Report of Open Market Operations.” FOMC Meeting. Washington, DC: Board of Governors of the Federal Reserve System: August 14, 1979b.

Friedman, Milton. "Monetary Policy: Theory and Practice.” Lecture delivered July 5, 1981; Journal of Money, Credit, and Banking, February 1982, 14(1), pp. 95-118.

Garino, David P. "St. Louis Fed Is Jubilant Over New Stress on the Money Supply in Monetary Policy." Wall Street Journal, October 9, 1979, p. 6.

Goodfriend, Marvin. "Monetary Mystique: Secrecy and Central Banking." Journal of Monetary Economics, January 1986, 17(1), pp. 63-92.

Greider, William. Secrets of the Temple: How the Federal Reserve Runs the Country. New York: Simon \& Schuster, 1987

Herman, Tom. "Bankers Foresee Problems in Executing And Enforcing Fed Anti-Inflation Plan.” Wall Street Journal, October 11, 1979, p. 6.

International Monetary Fund. Developments in the World Economy: Annual Report. Washington, DC: August 3, 1979.

Johannes, J.M. and Rasche, Robert H. "Predicting the Money Multiplier.” Journal of Monetary Economics, July 1979, 5, pp. 301-25.

Johannes, J.M. and Rasche, Robert H. "Monetary Control: The Implementation Experience, Retrospective and Prospective," in Karl Brunner, ed., A Symposium on the Federal Reserve and Its Public Accountability. Rochester, NY: Center for Research on Government Policy and Business, Graduate School of Management, University of Rochester, 1980, pp. 49-87.

Johannes, J.M. and Rasche, Robert H. "Can the Reserves Approach to Monetary Control Really Work?" Journal of Money, Credit, and Banking, August 1981, 13, pp. 298-313. 
Kichline, James L. FOMC Briefings. Washington, DC: Board of Governors of the Federal Reserve System: March 20, 1979a; April 17, 1979b; May 22, 1979c.

King, Mervyn. Address to the joint luncheon of the American Economic Association and the American Finance Association, Boston, MA, January 7, 2000.

Lindsey, David E. "Nonborrowed Reserve Targeting and Monetary Control," in Laurence H. Meyer, ed., Improving Money Stock Control. Boston: KluwerNijhoff Publishing, 1983; Presented at the conference Improving Money Stock Control: Problems, Solutions, and Consequences, co-sponsored by the Federal Reserve Bank of St. Louis and the Center for the Study of American Business, Washington University, St. Louis, MO, October 30, 1981.

Lindsey, David E. "The Monetary Regime of the Federal Reserve System,” in Colin D. Campbell and William R. Dougan, eds., Alternative Monetary Regimes. Baltimore: The Johns Hopkins University Press, 1986.

Lindsey, David E.; Farr, Helen T.; Gillum, Gary P.; Kopecky, Kenneth J. and Porter, Richard D. "ShortRun Monetary Control: Evidence under a NonBorrowed Reserve Operating Procedure." Journal of Monetary Economics, January 1984, 13(1), pp. $87-111$.

MacNeil-Lehrer News Hour. Transcript, October 10, 1979.

McCallum, Bennett T. "Robustness Properties of a Rule for Monetary Policy." Carnegie-Rochester Conference Series on Public Policy, 1988, 29, pp. 173-203.

Melton, William C. Inside the Fed: Making Monetary Policy. Homewood, IL: Dow Jones-Irwin, 1985.

Meltzer, Allan H. "Limits of Short-Run Stabilization Policy.” Economic Inquiry, 1987, 25, pp. 1-14

Meyer, Laurence H. A Term at the Fed: An Insider's View. New York: HarperCollins, 2004.

Orphanides, Athanasios. "Monetary Policy Rules and the Great Inflation." American Economic Review, May 2002, 92(2), pp. 115-20.
Orphanides, Athanasios. "The Quest for Prosperity without Inflation." Journal of Monetary Economics, April 2003a, 50(3), pp. 633-63.

Orphanides, Athanasios. "Historical Monetary Policy Analysis and the Taylor Rule." Journal of Monetary Economics, July 2003b, 50(5), pp. 983-1022.

Orphanides, Athanasios. "Monetary Policy Rules, Macroeconomic Stability and Inflation: A View from the Trenches." Journal of Money, Credit and Banking, April 2004, 36(2), pp. 151-175.

Orphanides, Athanasios and van Norden, Simon. "The Reliability of Inflation Forecasts Based on Output Gaps in Real Time.” Working Paper 2003-01, CIRANO, January 2003.

Orphanides, Athanasios and Williams, John C. "The Decline in Activist Stabilization Policy: Natural Rate Misperceptions, Learning and Expectations." Working Paper 337, European Central Bank, April 2004.

Rasche, Robert H.; Meltzer, Allan H; Sternlight, Peter D. and Axilrod, Stephen H. "Money, Credit and Banking Debate: Is the Federal Reserve's Monetary Control Procedure Misdirected?" Journal of Money, Credit, and Banking, February 1982, 14(1), pp. 119-47.

Shadow Open Market Committee. Policy Statement. February 4, 1980.

Sivesind, Charles and Hurley, Kevin. "Choosing an Operating Target for Monetary Policy." Quarterly Journal of Economics, February 1980, pp. 199-203.

Taylor, John B. "Discretion versus Policy Rules in Practice." Carnegie-Rochester Conference Series on Public Policy, December 1993, 39, pp. 195-214.

Taylor, John B., ed. Monetary Policy Rules. Chicago: University of Chicago Press, 1999.

Tinsley, P.A.; von zur Muehlen, P. and Fries, G. "The Short-Run Volatility of Money Stock Targeting." Journal of Monetary Economics, September 1982, 10(2), pp. 215-37. 


\section{Lindsey, Orphanides, Rasche}

Tobin, James. "On Consequences and Criticisms of Monetary Targeting, or Monetary Targeting: Dead at Last?: Comment." Journal of Money, Credit and Banking, November 1985, 17(4 Part 2), pp. 605-09.

Treaster, Joseph B. Paul Volcker: The Making of a Financial Legend. Hoboken, NJ: John Wiley \& Sons, 2004, pp. 61-62.

U.S. Congress Joint Economic Committee. Domestic and International Implications of the Federal Reserve's New Policy Actions. Hearings before the Subcommittee on International International, November 5, 1979. Washington, DC: Government Printing Office, 1980.

U.S. House of Representatives. "The New Federal Reserve Technical Procedures for Controlling Money," in Measurement and Control of the Money Supply. Hearings before the Subcommittee on Domestic Monetary Policy, March 20 \& 25, 1980. Washington, DC: Government Printing Office, 1980a.

U.S. House of Representatives. Conduct of Monetary Policy. Transcript. Committee on Banking, Finance and Urban Affairs. Washington, DC: Government Printing Office, February 18, 1980b.

U.S. House of Representatives. "Monetary Policy for 1980." Third Report by the Committee on Banking, Finance and Urban Affairs. House Report No. 96881. Washington, DC: Government Printing Office, April 15, 1980c.

U.S. Senate. Nomination of Paul A. Volcker. Hearings before the Committee on Banking, Housing, and Urban Affairs. Washington, DC: Government Printing Office, 1979.

U.S. Senate. "Federal Reserve's First Monetary Policy Report for 1980." Hearings before the Committee on Banking, Housing, and Urban Affairs. Washington, DC: Government Printing Office, February 25, 1980.

Volcker, Paul A. "The Contributions and Limitations of 'Monetary' Analysis.” Remarks before the American Economic Association and the American Finance Association, September 16, 1976 (reprinted in Federal Reserve Bank of New York Monthly Review, October 1976).

Volcker, Paul A. The Rediscovery of the Business Cycle. London: Free Press, 1978.

Volcker, Paul A. "A Time of Testing." Remarks before the American Bankers Association, October 9, 1979a.

Volcker, Paul A. Statement. Joint Economic Committee, U.S. Congress. Washington, DC: Government Printing Office, October 17, 1979b.

Volcker, Paul A. Remarks before the National Press Club, January 2, 1980a.

Volcker, Paul A. Prepared statement. Hearings before the Joint Economic Committee, U.S. Congress. Washington, DC: Government Printing Office, February 1, 1980b.

Volcker, Paul A. Statement. Committee on Banking, Housing, and Urban Affairs, U.S. Senate. Washington, DC: Government Printing Office, February 4, 1980c.

Volcker, Paul A. Statement. Committee on Banking, Finance and Urban Affairs, House of Representatives. Washington, DC: Government Printing Office, February 19, 1980d.

Volcker, Paul A. Remarks, "Economic Outlook for the 80s." January 15, 1980 (reprinted in Texas Business Executive, Summer 1980e).

Volcker, Paul A. Statement. Subcommittee on Domestic Monetary Policy of the Committee on Banking, Finance and Urban Affairs, House of Representatives. Washington, DC: Government Printing Office, November 19, $1980 f$.

Volcker, Paul A. Statement. Committee on Banking, Housing, and Urban Affairs, U.S. Senate. Washington, DC: Government Printing Office, February 25, 1981.

Volcker, Paul A. "Can We Survive Prosperity?" Remarks before the Joint Meeting of the American Economic Association and the American Finance Association, San Francisco, December 28, 1983. 
Volcker, Paul A. and Gyohten, Toyoo. Changing Fortunes: The World's Money and the Threat to American Leadership. New York: Times Books, 1992.

Wallich, Henry C. "Techniques of Monetary Policy.” Remarks before the Missouri Valley Economic Association, March 1, 1980.

Wallich, Henry C. and Keir, Peter. "The Role of Operating Guides in U. S. Monetary Policy: A Historical Review." Federal Reserve Bulletin, September 1979.

Wall Street Journal. "Quotes for Gold Continue Surging on New Rumors." September 18, 1979a, p. 3.

Wall Street Journal. "Fed, in a 4-3 Vote, Tightens Credit Reins By Lifting Discount Rate to Record 11\%." September 19, 1979b, p. 2.

Wall Street Journal. “Gold’s Price Surges \$24 an Ounce At London, Hits a Record \$375.75." September 19, 1979c, p. 8.

Wall Street Journal. "Gold Price Falls, Partly Recovers in Later Trading." September 20, 1979d, p. 2.

Wall Street Journal. "Fed Indicates It Wants Credit to Get Tighter.” September 20, 1979e, p. 5.

Wall Street Journal. "Rumors Send Prices in Gold, Other Markets into Day-Long Chaos." October 3, 1979f, p. 1.

Wall Street Journal. "Monetary Medicine: Fed's 'Cure' is Likely to Hurt in Short Run by Depressing Economy, Analysts Say.” October 9, 1979g, pp. 1, 6.

Wall Street Journal. "New York Fed Seeks to Lessen Confusion on Monetary Moves." October 10, 1979h, p 3. 
